\title{
Part IV: Legal Rights
}

It has previously been mentioned how hostages as rituals during peace processes - which in the sources may be described with an ambivalence, or ambiguity - and how people could be used as social capital in different conflicts. It is therefore important to understand how the persons who became hostages were vauled and how their new collective - the new household - responded to its new members and what was crucial for his or her status and participation in the new setting. All this may be related to the legal rights and special privileges, such as the right to wear coat of arms, weapons, or other status symbols. Personal rights could be regulated by agreements: oral, written, or even implied. Rights could also be related to the nature of the agreement itself, what kind of peace process the hostage occurred in and the type of hostage. But being a hostage also meant that a person was subjected to restrictions on freedom and mobility. What did such situations meant for the hostage-taking party? What were their privileges and obligations? To answer these questions, a point of departure will be Kosto's definition of hostages in continental and Mediterranean cultures around during the period 400-I400, when hostages were a form of security for the behaviour of other people.

\section{Hostages and law}

The hostage had its special role in legal contexts that could be related to the discussion in the introduction of the relationship between religion and law. The views on this subject are divided

\section{How to cite this book chapter:}

Olsson, S. 2019. Legal Rights. In: Olsson, S. The Hostages of Northmen: From the Viking Age to the Middle Ages. Pp. I 25-224. Stockholm: Stockholm University Press. DOI: https://doi.org/Io.I6993/bba.d License: CC-BY. 
among scholars. Sundqvist shows in an article on morality how the concept of siðr, 'custom', 'tradition', 'morality', or 'religion', could characterize traditional legislation. On the other hand, the Germanist Klaus von See argued that religion and justice were as different entities in the Old Scandinavian society. ${ }^{\mathrm{I}}$ As evidence, von See referred to a few procedural texts in which the concepts $\log$ (law) and siðr appear distinctly separated from each other, as in the Íslendingabók: hofum allir ein log ok einn sið ('one is to keep one law and one religion/ritual/custom'). According to Sundqvist, there are texts that contradict this, such as the Norweigian Frostathing law $(\mathrm{I}, 3)$ : Enn um siðsemi á Frostopingi ('and through a custom at the Frostating'). In Egil's saga, 'law' and siðr appear as equivalent concepts during a negotiation at the Gulating (ON Gulaping). ${ }^{2}$

Hostages could also be linked to laws and thus indirectly to siðr. The link between hostages and laws can be relevant for the understanding of the hostage as a ritual tradition. Written agreements are - although they are not laws - legally binding and can therefore function as an instrument of power.

The only preserved written agreement from the Viking Age that includes Scandinavians and an agrement on hostages is the settlement between Guthrum and Æthelred. However, oral agreements would have been binding because several peace negotiations between Scandinavians and Anglo-Saxons involved hostages according to the Anglo-Saxon Chronicle, as previously mentioned. Even if these 'oral agreements' do not mention the exact role of the hostage, we can assume that they implicitly stipulated that the hostage should be respected.

In Norwegian and Swedish medieval legislation, hostages are mentioned in different contexts. These texts are remnants of old traditions, which we can refer to as siðr. The hostage cannot be directly linked to this concept in the texts, but words of hostage appear in formal expressions and in ceremonial contexts, that is, in traditional contexts.

\section{Selection of hostages}

In peace processes, a particular selection of hostages occurred. After a conflict, both sides tried to manoeuvre from an advantageous 
position when it came to determining who would be hostages in both unilateral and bilateral peace agreements. The selection was due to what degree one side was subjected to the other, but at the same time it could be a game in which the opposing party tried to get as good hostage as possible, preferably a person with special qualities. Different variants of hostage givings may have given room for some maneuvering regarding the selection. This game is imprinted in myths and stories as well as in a cultic behaviour. Who then were the hostages and why were they selected? In order for a hostage to act as security for both party and it must have had a definite social value. The person who would be hostage must have been in some kind of close relationship with the person, or persons, whom he or she was a guarantee of. Generally in Continental Germanic societies, children (mainly sons), parents and relatives were the ones preferred. Persons who were not relatives but who appeared within the framework of 'friendship' could also be hostages. ${ }^{3}$ In the continental forms of hostages, Kosto explains: to serve as hostage was 'almost a standard element in the curriculum vitae of a medieval prince'. ${ }^{4}$

There are many similarities with being a hostage and a foster child, but there are also some differences. Basically, to be a hostage meant that you were given as a security for other persons during, before, or after negotiations, as has been discussed earlier in this book. The fosterage, on the other hand, was not the result of a conflict but a formal agreement between families or groupings, i.e. a social bond. In the Icelandic law Grágás, the rights of the foster child is described: The fosterage period was between the ages of eight and sixteen. The fosterfather received a so called fóstrlaun, a compensation, for the costs of fostering the child. It was the right of the father to bring a child back home if the child was being mistreated, and then the provision would return the child. This was also the case if the child was sent home by the foster parents. But if the father took away the child without cause, then the provision would remain at the foster home. The heirs of the foster parents had the right to take over the tutelage and the compensation. ${ }^{5}$ This was the difference between being a hostage and a fosterchild: In the former case the time of the hostageship could last could last for a lifetime, while a period as foster child lasted 
for eight years. The return of the hostage was a decision by the hostage giver, which was also due to altering political conditions such as the outcome of a war. A hostage could not be released for money unless they became prisoners of war. The biological father of a foster child still had the opportunity to retribute his children when he wished to do so.

The fostering will be further discussed in this part of the book. We will now turn to the role of the female hostages.

\section{Women hostages}

Could women become hostages during the Viking Age? In the time of Ancient Rome, Germanic peoples took female hostages according to Tacitus (see further below). Kosto considers that information uncertain. He points out: that are only 'a handful of' sources from antiquity, their source value can be questioned, and there are even fewer from the 8th to the Ioth century, but from about I 200 , female hostages became routine. They were, however, disconnected from their families. Instead, Kosto claims that they were handed out as wives. ${ }^{6}$

The procedure with women given as wives is precisely described in the Annales Alamannici: Conrad I of Germany and Erchanger, Duke of Swabia, established peace. In 9 3 Conrad was married to Erchanger's sister, Cunigunde, who is described in the annals as a 'peace hostage' (tamquam obsidem pacis). ${ }^{7}$

Tacitus depicts, in Histories (Historiae), negotiations between the Romans and romanized Ubians in the colony of Agrippina (Cologne) and the Romans during the Batavian rebellion (69-70 AD). The revolution leaders Civilis and Classicus had given some of their relatives as hostages of the the Agrippinenses in the colony including Civilis's wife and a daughter of Classicus. ${ }^{8}$ The wife of Civilis was hardly a possible potential wife for the hostage takers or their nearest circle, though she had an important symbolic function as a wife of Civilis. By contrast, Classicus's daughter could have been used in a marriage arrangement. However, in order for a marriage to be concluded, one must first reach a standstill. The example may possibly indicate different motives for taking a woman as hostage. 
Another case may be the bishop of Lyon, Eucherius (d. 449), who depicted the siege of the Visigoths on the Gallo-Roman city of Bazas (or Civitas Vasatica) in Aquitaine in 4I4. The Roman poet Paulinus of Pella became hostage of the ruler of the Visigoths, Athaulf. In return, the Romans recieved an Alanian 'queen' and a 'prince'. 9 Here, as in the case of the wife of Civilis, it was a question of a married woman because she is called 'queen'. Thus, these cases represent two exceptions to the general rule that there were unmarried women who acted as hostages. There may also be examples of forced labor in connection with war and robbery. In the epic poem Beowulf, the modifier Weolh-, in Weolhpeow's name, could mean 'celtic', 'foreign', or 'slave' and the head -peos could have the meaning of 'slave', 'servant', or possibly 'prisoner'. ${ }^{\text {Io }}$

According to the chronicle Annales Vedastini from the Abbey of St. Vaast in Arras, a 'Norman king', Godefrid (Godefridus), attacked Emperor Charles the Fat in 882. Charles would have given Friesland to Godefrid and married him to Gisela (or Gisla), King Lothar's daughter, for the promise that the Normans would leave the kingdom. Gisela's function was like a hostage because the marriage was a guarantee that Godefrid would not attack again. ${ }^{\text {I }}$

The question is then how to interpret the sparse evidence that describes women as hostages between 500 and I000. Kosto points out that from the I Ith century, 'women, and most often daughters, regularly served as hostages per se'; before that, daughters were given as wives rather than hostages. ${ }^{\mathrm{I} 2}$ Kershaw, on the other hand, mentions that 'with few exceptions [the women] were all adults, aristocratic but left to the dominant party'. ${ }^{\text {I3 }}$ Kosto claims to have found only seven cases of female hostages during the period $400-900 \mathrm{AD}^{\mathrm{I}}{ }^{\mathrm{H}}$

Rather than going into the details of Kosto's and Kershaw's arguments, I should like to problematize the image of the woman's position before the new collective. For example, how should one interpret this statement in the Piðreks saga: 'She was often put as hostage' (Hon war tit sat till gisl)? ${ }^{\text {I5 }}$ Does it suggest that the person in question was used as a hostage, also when married, and still had a certain social value? The Piðreks saga can be rejected as unreliable as it is a late source (fixed in writing in the 13 th century), 
but such data on sources are generally often uncertain. With this example I simply want to emphasize that women may have had changing status and, depending on culturual values, could have been valued differently in connection with marriage alliances.

The fact that women could be politically important during 'The Dark Ages' (The Migration Period of c. 400 to 800 AD) can be illustrated by an example involving Theodoric the Great. After a feud with the Kingdom of Thuringia, Theodoric married his niece Amalaberga to the ruler Hermanfrid (532). Amalaberga brought a letter of introduction to her husband-to-be, which described her skills; she was assumed to have skills that were important in her future marriage. ${ }^{16}$

In general in the Old Scandinavian society, women were regarded as representatives of the household (cf. husfrú). Although it is uncertain whether they participated in war actions, they may have had certain roles in the context of peace and warfare. These functions made them - based on Kosto's statement that they were given as wives - interesting as actors regarding in peace processes. At the same time, the sources - both continental and Old Norse leave no room for any far-reaching conclusions as to whether women became hostages. We will return to the cultural and social roles of women in war and peace later.

\section{The game of hostages}

In a few ancient and medieval stories, the value of the hostage is indicated by the will to maintain it. Perhaps, therefore, a tactical game was displayed to keep important persons. This can be seen in the story of the birth of the Roman festival Nonae Caprotinae (7 July). According to Bíoi Parállèloi, 'parallel biographies', by Plutarch, the Romans were threatened by the Latin under the command of Livius Postumius. ${ }^{17}$

The commander Livius deployed his troops not far from Rome, sending a hero with the message that the Latins wanted to renew their friendship with the Romans through marriage alliances. The Romans were invited to send many maidens, or widows, in exchange for friendship and peace as they had done before with the Sabins. The Romans hesitated regarding what to do: either 
handing over their women - which they thought were the same as sending them to captivity - or go to war. A maid (ancilla) called Tutula, or Philotis, advised them to use a stratagem. She and other maids dressed up to resemble the free-born Roman women and were sent to the Latins. At night they would light a signal fire for the Romans, who would sneak into the camp. This was done; a fig tree was ignited, and the Romans could surprise their enemies. In memory of this event, the festival Capratine ('Figs') was celebrated, during which maidens went into Rome in a procession, while joking with people, performed a ritual battle, and feasted in the shadow of figs. Plutarch, however, is careful to point out that this is a legend and that the festival could also have been celebrated in memory of Romulus's passing. ${ }^{18}$

According to the myth about the war between the Æsir and the Vanir, the Æsir obviously used a stratagem to fool the Vanir in the exchange of hostage, which may have involved to ursurp the powers of the goddess Freyja. Implicitly in this myth, there was the will to keep-deities with a special symbolic capital.

The game about the selection of hostages - where it was important for the hostage giver to keep and for the taker to get a person of as high a value as possible - can be compared with a gift-giving institutional custom described by the anthropologist Annette Weiner, who was inspired by Mauss. Weiner formulated through the paradox 'Keeping-While-Giving' the idea that some items were too valuable to be transferred to others. ${ }^{19}$ At the same time, it is important to point out differences between cultures. Lavelle claims that it was voluntary to enter as a hostage in the AngloSaxon society, even if the other side could influence or dictate the peace agreement. ${ }^{20}$ There are indications of similar approaches to agreements and peace processes in areas of confrontation involving Scandinavians. For example, at the siege of Apuole in Courland 854 (see further below), there was a willingness among some citizens to volunteer as hostages to the Swedes even though the degree of 'volunteering' can be discussed.

As the hostage owner did not have full control of the identity of the hostage, the knowledge of who was appointed must have been essential. This reasoning will further be developed below and in the next parts. 
Hostages in different peace processes must have had a certain social value, a social capital. Otherwise they would not have been used. Perhaps the value of hostages may have been reflected in what we today refer to as their 'legal capacity' if they were attending the negotiations. The legal historian Gabriele von Olberg claims that the hostage itself had a 'legal capacity' because it could serve as witness. As a source, she uses a paragraph from the Lombard law, Edictus Rothari: gisil id est testis, 'hostage, that is the witness' ${ }^{21}$ An example from another time period may confirm this. In 4 I 4, during the siege of Bazas (or Civitas Vasatica) in Aquitania, the Roman poet Paulinus of Pella went as a negotiator to the ruler Athaulf of the Visigoths and ended as a hostage. ${ }^{22}$ In the Old Irish The Airgialla Charter Poem (written in the seventh century), it is described without ambiguity that persons who would be hostages witnessed and swore oaths during a peace treaty (see the The Airgíalla Charter Poem, part V). Naturally this was due to the conditions in Gaelic Ireland. Implicitly, one can assume that the hostage generally witnessed peace treaties. However, I have not found any evidence in peace talks that included Scandinavians and where the hostage was actively able to influence the negotiations except for I6th century Sweden (see the final part).

Kosto believes that the status of the Continental Germanic hostage was reflected in how the hostage was treated - or could be expected to be treated - because they came from well-off homes:

Because of the nature of the sources, particularly for earlier periods, most of the hostages we know about were either noble or wealthy enough to merit (or negotiate) good treatment. Furthermore, many hostages of lower status were handed over pursuant to agreements negotiated by powerful people and thus the conditions of their confinement reflected their patron's influence. When hostages are treated well, in other words, it is as likely to be because of who they were as because of their status as hostages. ${ }^{23}$

In addition, it may be added that the persons who decided who would be hostages - and handed them over - could play a decisive role as much as the ones who received them. Whoever gave hostages may have relied on the nature of the agreement, the 
degree of dependence to the victorious side, and how the bonds of 'friendship' were expressed. The giver and the recipient of the hostage were responsible for the delivery according to the 'regulations', and they must have been percieved to have 'legal capacity' and to be authorized to take part in the negotiation and drafting of the peace agreement.

Naturally, the decision could lie with the one who exercised the greatest influence over the peace process, the winning side. This is given in the case of the Roman Empire, which could affect hostages through various agreements. But such a power-making ruling may have been less evident in other and later cultures, such as the Continental Germanic, at least if there were settlements between fairly equal parties. Even in the Roman Empire it was complicated to decide on peace and hostages because these judgments were partly ritualistic in their character. The Romans used different types of war treaties. The treaty foedus deditio meant that a defeated country submitted to the Romans without reservation. The war treaty, foedus aequum, was used when Rome negotiated with a country whose sovereignty they could, or would, not restrict, i.e., fairly equal nations such as Carthage before the final defeat or Parthia. The foedus iniquum meant that the new partner was obliged to respect Rome's sovereignty. Hostages were used as security in all treaties. ${ }^{24}$ During the negotiations a group of cult specialists were present: the fetials (fetiales). ${ }^{25}$ The fetials accompanied the hostages when they were delivered. These specialists appear to have had influence over both the declaration of war and the taking of hostages. Before peace processes, Roman commanders were obliged to relate to activities and decisions of the fetials, especially during the times of the Kingdom and the Republic. During the Empire, their influence seems to have diminished. Such cult specialists are found neither in Continental Germanic nor in pre-Scandinavian traditions.

In Old English sources it is mentioned how ealdormen and bishops are mentioned regarding the surrender of hostages. ${ }^{26}$ These officers were members of the king's counsel and could influence the election of the king. Similar functions can be attributed to the lawmen and bishops mentioned in the Elder Westrogothic Law. These were also able to influence the outcome of the royal election. 
In the Swedish realm, a lawman appointed the hostage to be taken to the border between Östergötland and Västergötland during the king's journey in the 13 th century, the Eriksgata (see the final part). ${ }^{27}$

These latter cases with clergys and lawmen refer to Old English and medieval Scandinavian contexts, but, as with the Roman cult specialists, they routinely discussed peace processes and thus how to use the hostage. ${ }^{28}$ Another common factor during the early Middle Ages was that the ecclesiastical power was able to express its views on peaces. Hence, various rulers had to relate to people with both worldly and spiritual office when they made decisions.

Generally, in the context of peace processes, other persons or groupings, for example in a parliamentary assembly, as in the case of the peace meeting between Harald Hardrada and Sweyn Estridsson at at Göta älv (River of the Geats), could influence the outcome (see further below). All these groupings - great men or nobility, men belonging to the worldly or the ecclesiastical spherescould directly or indirectly influence decisions including the appointment of hostages.

According to Annales Bertianni, some 'pirates' attacked parts of Friesland in 839 and caused major damages to the border areas, including the Danish parts of Friesland. The Danish ruler Horic then sent an embassy to the Frankish emperor Louis the Pious. ${ }^{29}$ He also sent his nephew (nepos) and gifts. One of the messengers was a man whose advice Horic seem to have paid attention to more than anyone else. With this embassy, Horic would consolidate the peace and the alliance, which was maintained between his lands and the Frankish empire. ${ }^{\circ}$ The episode in Annales Bertianni contains no explicit information regarding whether Horic's nephew would be a hostage to secure peace, even if this was the case. The role assigned to Horic's adviser is more relevant. The messenger seems to have been the one authorised to negotiate and was responsible for the delivery of the gifts. Hypothetically, he could also have been the one who surrendered the hostage.

The sources are often written from clear perspectives. The medieval writers chose - possibly based on their own interests sometimes to focus on rulers, sometimes on others. Next, such a hostage case will be discussed. 


\section{The peace between Magnus the Good and Harthacnut}

A peace agreement between the Norwegian king Magnus the Good (Magnús góði) and the Danish ruler Canute III Hathacnut (ON Harðacnut or Horða-Knútr) in about I036 is mentioned in Ágrip: ${ }^{31}$

However, in Denmark Sveinn had died and so had his father Knútr in England, and Denmark was then ruled by Sveinn's brother, who was called Hǫrða-Knútr, and he led an army against Magnús and they met at Brenneyjar. Wise men acted as intermediaries and an agreement was proposed and made in such a way that since Họrða-Knútr thought he had rightful claim to Norway because his father had won it and his brother had ruled it - and Magnús thought too that his father had suffered great wrong at the hands of Knútr, betrayal, exile, death - this agreement was reached: the one who lived the longer was to rule both countries, but each would rule his own kingdom while both lived. Then hostages were exchanged. Knútr died first, and Magnús then took Denmark without opposition, because the sons of the most important men were held hostage. ${ }^{32}$

(Transl. Matthew J. Driscoll)

The background was that Magnus - who was the son of Olaf II Haraldsson and born out of marriage - had been raised in Novgorod. With the help of Swedish and Norwegian great men, he managed to expel the King of Norway, Svein Knutsson (ON Sveinn Knútsson), son of Canute the Great. Magnus had been coronated King of Norway in I035. Harthacnut of Denmark, Svein's brother, then tried to take the Norwegian throne, something he considered himself entitled to since his father was King of England, Denmark, and Norway. War and negotiations followed. ${ }^{33}$

As mentioned, the two kings meet at the islands called Brenneyjar, in the archipelago of presentday Gothenburg, for negotiations. They concluded a treaty with the agreement that if one outlived the other, he should take over his kingdom. The treaty is referred to in both Norwegian and Danish texts, but historians consider them to have a low historical source value. The historian Claus Krag comments on this in Aschehoug's History of Norway: 
Both the later sagas and Danish chronicles explain what happened when Magnus and Harthacnut had already entered into an agreement in 1036 that the one who lived the longest would inherit the other. But there are no hints about any such agreement in the contemporary sources, and most historians in recent times have therefore assumed that the agreement has never existed. ${ }^{34}$

Despite the low source value, it may be of interest to look more closely at how the various writers and chroniclers reproduce the event. The chronicles, kings' sagas and annals describing the episode use a terminology that differ between different works and therefore can give different perspectives on the story. Of these sources, Ágrip's version is most relevant because it exemplifies the role that the hostage could have in conflict. It also has a darker view of the actions of the kings than other versions.

I will also tend to the other sources to compare differences and similarities. In that way, it is possible to discern the different views of the different writers. For example, in Ágrip's version, 'wise men' (vitrir menn) have an influence over the peace process. In other versions (see below), it is claimed that it was Magnus's and Harthacnut's low age that was the reason why other men who ruled their kingdoms had to deal with the negotiations and arranged settlement and peace, but that is not evident in Ágrip. The kings appear as fully capabale players who could lead armies against each other. No willingness to establish peace is noted. Instead, the mediators utilize a stratagem by arranging it so that both kings can retreat without losing face through the deal.

In the quoted paragraph there is no word for peace, for example, friðr. Instead there is a word for peaceful settlement, scett. The word friðr is ambiguous, and in the Icelandic skaldic language it could mean: (I) 'love', (2) 'friendship', (3) 'peace, peaceful relationship', (4) 'peaceful living', and (5) 'heavenly peace, bliss'. ON friðr can also have the double meaning of 'peace' in general or 'peace' in the Christian sense, but it may also refer to 'settlement, truce'. Peace can sometimes be described in texts with the less ambiguous ON grið, 'safety for life and limbs, armistice, truce'. ${ }^{35}$

The word satt, 'settlement, agreement', is thus used in the above paragraph to describe the peace. The term indicates that 
this kind of agreement was so fragile that it had to be secured with hostages. It is not evident from the text what influence the great men had on the actual arrangement with the hostages, because the kings are depicted as competitive warlords, but it is quite possible that it was a part of their scheme.

After the death of Harthacnut, Magnus was able to secure his position as ruler in Denmark, since he possessed the hostages. Reading this paragraph gives room for several interpretations where different wills are set against each other. Obviously, the 'wise men' are a part of this. Men like these were surely made up of bishops and lawmen, because they had knowledge of what could be called 'state affairs', but there were probably other great men, perhaps war chieftains, who served as intermediaries. These events correspond to some of the processes that I described in my model. The rulers were not entirely self-determined when it came to how peace would end. The area of confrontation was here, as well as in some other conflicts between Norwegian and Danish rulers in the IIth century, the outflow of Göta älv where the Brenneyjar formed the area of communication. However, Ágrip reproduces events that are $150-200$ years back in time and other sources partly contradict this version.

\section{Norweigian and Icelandic sources}

In other sources, the tone is softer in terms of the actions of the kings. Indeed, in Fagrskinnas version, the encounter is described in almost mythical words: one meets at the river (the river Göta älv) and the aim is to achieve a 'world peace' (veraldarfrið), which should last as long as the 'world is in existence' and 'for ever' (allan aldr). The agreement also in this version arranged by the 'foremost men' (enir beztu menn) from the retinue - the hird - of each king. Twelve of the richest men from each kingdom swear to keep the peace as long as they live. This version does not mention any threats from either of the two kings. The treaty between Magnus and Harthacnut is described as brotherly: 'Then King Magnus will have the whole kingdom, and to be heir shall be his right, as his [Harthacnut] born brother' (pá skal Magnús konungr eiga allt ríki ok vera arftokumaðr hans réttr, sem borinn bróðir 
hans). ${ }^{36}$ In this version the great men have lesser ability to maneuver in relations to the kings. In this case there is a reference to the (peace) meeting (stefna) at the river where the kings had previously made peace ( friðr). This can be an indication that it was a matter of routines and hence tradition. Here too, the word satt is used to describe the agreement.

In Heimskringla's version of the Saga of Magnus Góði (Uphaf Magnús konungs goða), decisions seem to be taken by the officials rather than by the kings. Magnus and Harthacnut travel with their fleets (ledungs) up to the river (Elfr) for a battle. However, learned men (lender menn) in each army send messages to their relatives and friends that they will make peace between the kings. Since the kings are too young, their realms are run by great men (rikismenn) who were elected in each country. A conciliation meeting is agreed in the name of both kings. They meet and talk about conciliation (sáttmál). It ends with the kings becoming brothers (broðralag); they make a peace agreement and decide about the succession. ${ }^{37}$

In this version, the kings are united in brotherly love, which could be a topos or literary feature, as well as the fact that both countries are represented as each other's reflection: the great men call upon each other and the succession is established equally. At the same time, other men are credited with the success of the peace work; the two kings are too young to influence the outcome..$^{3}$ Even according to this version, $\mathrm{I} 2$ of the finest (ágæetastir) men of each kigdom swear to keep the peace.

Morkinskinna's version does not differ essentially from the ones in Fagrskinna or Heimskringla except for the beginning of the story where householders (or farmers) exercise a significant influence over the peace: ${ }^{39}$

When the warfare between the kings had gone on for a time, each succeeded in wreaking much damage on the other. This was a burden on the farmers, and they were eager to improve relations between the kings. The farmers from both realms assembled and consulted wisely and propitiously on behalf of the kings, who were both young men, amenable and willing to be guided by their followers. They arranged a meeting at the River Elfr (Götaälv). ${ }^{\circ}$

(Transl. Theodore M. Andersson and Kari E. Gade) 
Otherwise, Morkinskinna follows the other chronicle and saga traditions. Nevertheless, the householders hold their own meeting, which does not appear in the other texts in which 'envoys' are mentioned.

In the Icelandic Knytlinga saga, it is only mentioned that Harthacnut takes control of England and Denmark and that Magnus, the son of St. Olaf, controls Norway and is 'brother of oath' with Harthacnut. ${ }^{4 \mathrm{I}}$ The author, who may have been the Icelandic skald Ólafr Pórðarson hvítaskáld (d. I 259), ${ }^{42}$ refers only to other Norwegian kings' sagas in this case.

The Norwegian chronicle of the kings, Chronicon Regum Norvegice, written in Latin, is laconic, but contains all the basic elements found in the other versions. Here too, the low age of the kings is mentioned, how nobility worked on both sides to achieve a settlement with peace, and and an agreement on the succession, which was confirmed with an oath endorsed by a grouping of nobility. ${ }^{43}$

To conclude: The details of the peace meeting with related terminology regarding the meeting place and the hostage exchange seem to have been of less interest for the writers than details about the intentions and actions of the kings and the great men. It is probably due to the purpose of the writers to legitimise the kings' power.

The fact that, in some cases, the writers used a terminology that, in earlier times, was associated with peace processes may indicate that the episode in Morkinskinna could have had an older story as a frame. The islands of Brenneyjar as well as Göta Älv were meeting and trading places during the Viking Age and the Middle Ages.

\section{Danish sources}

Danish sources - mainly chronicles and annals - are generally more laconic. In the 'Annals of Ryd' (Annales Ryenses) from I 288 , it is mentioned that when Harthacnut learned that Magnus had become king of Norway, he sailed with Danish and English ships to Norway. It is also mentioned that the friends of Harthacnut and Magnus made a standstill (saance) between them and that they agreed that the one who lived the longest would have both realms. ${ }^{44}$ 
2I, 2 While this happening, Cnut, as deeply upset by the report of Norway's treachery as he was by that of his father's death, began to be worried, for if he turned his efforts to with his neighbours, in the delay caused by his absence he might find himself deprived of England; he therefore judged it more prudent to tolerate the revolt of the lesser country than give an opportunity to the larger one for a similar attempt; he considered that the fear alone of a graver event outweighed a smaller distress. For this reason he concealed his displeasure at the insult and approached the rebel with certain terms, stipulating on oath that whichever of them died first should yield his kingdom to the survivor, this would avoid a situation where a new division of the realms tore apart the old acknowledged authority and divided the supreme power, which had formerly had the advantages of unity. So he strove to keep Denmark and Norway under a single command, his preference being to subordinate one to the other instead of letting each exercise rule individually; he would rather foreigners held sway over his country than that his country should exclude foreigners from those it governed. Surely that agreement, inasmuch as it was more subject to chance, came all the nearer to foolishness, in that it would produce for one or the other realm either a glorious sovereignty or mean servitude. Each party took an oath agreeing to abide by the convenant. ${ }^{45}$

(Transl. Peter Fisher)

According to this version, it is of loyalty to Denmark that Harthacnut entered into the agreement with Magnus. There is no mentioning of a mediation by great men from both sides. Instead, it is entirely Harthacnut's own initiative that saved Denmark from fragmentation.

The Danish chronicle traditions differ from the Norwegian by merely implying that the meeting took place at the river of Göta älv. Perhaps the Danish chronicle tradition are independent of the Norwegian, but here too is the problem of time discrepancy and especially in Gesta Danorum - the tendency to legitimize the Danish royal power. The texts give different explanations of how and why the meeting would have taken place, with dissimilar descriptions of the characteristics of the two kingdoms. The accounts of the kings' decision to meet differ between the sources as well as the depiction of the men who - in some versions - independently made decisions. 
Obviously the mentionening of hostage in Ágrip appears to be a remission. Whether the version of Ágrip - the oldest of these texts really can build on actual information cannot be determined with certainty. What can be noted is that the same terminology was used during peace processes in both the Viking Age and the early Middle Ages. Whether the contexts say anything about a real situation is uncertain, though.

In the next chapter the question is brought up whether hostages as described in different chronicles and in saga literature - could have been perceived as a symbolic subordination or not.

\section{Subordination and triumph: Different opinions}

In the Roman Empire, the arrival of the hostage was a triumphal ritual act. The historian of ideas Joel Allen describes how such a procession with the hostage would appear. The case concerns the Roman politician and general Titus Quinctius Flaminius who returned to Rome in $\mathrm{I} 94 \mathrm{BC}$ and was awarded a triumph after several victories, not least against Philip V of Macedonia, who gave his support to Hannibal during the Second Punic War:

As Livy [34: 52] tells it, the festivities lasted for three days, with a parade of unusual riches and spectacles of a Roman triumph [...]. Works of art, weapons caches, and wagons loaded with ingots of precious metals and mounds of coins were carted through the streets. Brightly colored placards and tableaux would have depicted events in the war, as well as conquered territories, city walls breeched by the Romans [...]. A horde of prisoners of war would have chocked the streets, hundreds of them destined for slavery. Such an array of conquest must have been deeply impressive to the audience [...]. [-] The climax of the third day, when dozens of Greek boys trudged along in front of Flaminius, who as the triumphator, would have appeared as a near-god decked in purple and with his face painted in red as he rode in a four-horse chariot up to join Jupiter on the Capitoline Hill. The Greek youths before him were about twenty-five in number [...]. [-] Viewed together, they formed a memorable entourage: as children of the nobility, all of them would have been well dressed; as adolescents, many of them would have been gangly and uncomfortable, both 
in Rome and their own skins. [...], failing to understand the Latin cries all around them, making their way before Flaminius's chariot, which bore down on them from behind, [...], the hostages must have seemed utterly pathetic and powerless. That appears to have been the point: here at zenith of the triumph, the man responsible for it all came shepherding a final and peculiar asset for Rome's future, a next generation. ${ }^{46}$

Allen describes what was central in the use of hostages in ancient Rome. It was first and foremost a symbolic expression of the victory of Rome and utilized in the triumphs that were granted to certain generals. The hostage was placed in front of the triumph wagon, a place that was also reserved for the most valuable spoils of war after a campaign. ${ }^{47}$ But hostages also represented an 'investment' in the future, as the Macedonian boys could become future leaders in their home country. They also provided valuable capital of knowledge because they were educated in the Greek intellectual traditions, which had a strong impact on the Romans. The boys thus had valuable functions in addition to be a security for the behaviour of their parents.

In the Old Scandinavian and Continental Germanic communities, similar beliefs about hostages may have occurred even if one must be aware of the different societal conditions for of these cultures. The taking and display (in public) of hostages may, in some cases, reflect a symbolic submission, but in some cases it may not be that obvious.

Lavelle discusses whether the hostage was a triumph for the hostage taker or a subordination for the donor in the AngloSaxon society. Neither the legal functionality of hostage, nor its practical and symbolic values was the only dominant factor for the 'hostageship', ${ }^{4}$ But for writers and chroniclers, it could be a way of demonstrating a ruler's triumph over Viking leaders:

[T] he taking of Viking hostages by West Saxon kings (both Alfred and Edward the Elder) remained one convenient shorthand way for writers to demonstrate power, even where the kings' actions may have been motivated more by practical necessity and where tangible authority may have been less apparent. Therefore, it may be concluded that the importance of hostages lay in the mixture of 
the practical threat with political status. The rituals inherent in the making of peace presumably remained important, but the different circumstances under which hostages were used (peacemaking with external enemies, the assertion of the submission of external enemies, the assertion of lordship within the Anglo-Saxon kingdom and the use of local legal guarantees) show a flexible application of hostageship - or at least multi-layered meanings of hostage-holding which are not always immediately perceptible in the sources. The flexible use of and abuse of hostages show that both Anglo-Saxon rulers and their opponents could be far more imaginative in their dealings than we sometimes give them credit for. ${ }^{49}$

Lavelle points out something central: for the chroniclers, the moment of submission was important just as to portray 'strangers' and 'pagans' like those who broke the hostage agreement. Lavelle's examples, however, are limited to Anglo-Saxon England about 800-I000. A comparison between different chronicle traditions would reveal how complex the reality was, as Lavelle suggests. Even what Lavelle regards as less important - the legal and symbolic value of the institution surrounding the hostage - could be emphasized. It is necessary to turn to both Old Norse and Continental Germanic sources to discuss the hostage in a broader perspective. In this part, it is discussed how men from the groupings around great men were treated as hostages. The intention is to investigate the different political and religious contexts they encountered. The role of women is also discerned. In addition, both the major forms of hostages that Kosto defines as bilateral and unilateral, as well as the breaking of oaths and cases of violence against hostages en masse, are scrutinezed.

\section{Submissions}

Total submission involving hostages seems rarely to have occurred, possibly except for in ancient Rome, especially during the imperial era. An example from the antique world with a similar category - a prisoner - could illustrate a symbolic exposure of a total submission: Caesar mentions in his comments on the Gallic War (Commentarii de Bello Gallico) how Vercingetorix, the ruler of the Gauls, was handed over to the Romans after the battle of Alesia in $52 \mathrm{BC}$ and 
threw his arms to Caesar's feet; despite this, he was later executed by Caesar..$^{\circ}$

A more recent symbolic exposure of submission - which involved hostages - can be seen in the story of Niall Noígíallach, whose legendary epithet can be interpreted: 'he who has nine hostages'. The name Noígíallach is probably fictitious, but it may have been used to embellish the ruler and thus legitimize the king's power in a later period. A stanza by Sigvatr skald (Sigvatr Pórðarson) (Sigvatr Thórðarson) in the memorial poem of St. Olaf (Erfidrápa Óláfs helga) can be linked to a similar context:

(2) Upplönd fekk til enda

óss neista ok par reisti

kristnihald pats heldu

hvers veitir, sverðs beitar.

Àðr stýrðu peim eyðar

ellifu fyrr hella

mildings máls enn guldu

menn vísliga gísla. ${ }^{51}$

The giver of gold (i.e., the king) conquered the Highlands to each end (i.e., from border to border), and established Christianity there, which the sword-wielders (men) kept. Eleven kings (lit., wasters of the cave-lord's interest) ruled them (i.e., the Highlands), but the men wisely gave up hostages. ${ }^{52}$

(Transl. Jón Skaptason)

In these cases, it was the prerogative of the victor to receive the hostage and dictate the terms of his or her time as hostage. At the same time, there may be a difference between text and reality. This can be seen in another example of a possible total submission involving hostages, in the Carolingian Annales Bertiniani. It depicts how the Saxons fought the colodici, a Sorbic tribe, at a place called Kesigesburg (location unknown) in 839, a fight that ended with the death of the Sorbian ruler (regeque ipsum) Cimusclus (or Czimislav). The Saxons - then Christians - managed to defeat the Sorbs 'with divine aid' (celestibus auxiliis fulti). A new 'king' $($ rex) was elected by the Sorbians, and the Saxons took an oath of 
loyalty from him. He gave hostages and some of the lands of the colodici were confiscated. ${ }^{53}$

The chronicle reveals what may be a cliché of continental chronicles: the idea that it was divine intervention that made the Christian Saxons triumphant. The information about a Saxon victory does not necessarily have to be wrong, but it may have taken a long period before peace had been achieved. Why was the hostage needed if a tributary king was deployed and the Sorbs swore oaths? Was not the Christian victory total? The text does not mention if the Sorbs in this case were Christianised. In this case, the hostage implicitly functioned as assuring the obedience of the Sorbian ruler, but in the text it is mentioned as part of a submission in addition to the taking of oaths and the conquest of land areas. This is comparable to how the hostage was often given by the Saxons during the confrontations with the Carolingian Empire, but they often broke the peace despite hostages. How subjected the Sorbs really were by the Saxons can thus be open to discussion. Annals can provide incorrect information about the role of hostages. They have been recorded by monks who although they were active in the ninth century - were far from the area that is described. The Carolingian Emperor, the victory of the Christian side, and theological questions about miracles were the themes that were most central to them, while themes of realpolitik became less important.

There are several examples of how the victory over heathen enemies is described in a triumphal way by chroniclers. The hostages in their texts are mentioned as an important part of the victory as well as the baptism of the defeated enemies. The specialist in Old English Peter S. Baker points out that peace negotiations were often followed by forced repentance, ${ }^{54}$ and Lynch gives the baptism of Guthrum as an example of such submission. ${ }^{55}$ However, the comments of Lynch and Baker may be taken with a pinch of salt. In Part I, I discussed the possible actual situation based on strength and geographical relations between the realms of Alfred and Guthrum. The willingness of the 'heathens' to accept baptism may have been of political nature and represented a syncretistic or acculturative attitude where the Christian deity was not necessarily understood in the same way as within Christianity. ${ }^{56}$ Thus, 
there may have been many ways the hostage was perceived when heathens and Christians met for negotiations. Kosto points out how the sources are often written from a subjective perspective:

[...] the sources, most written from the perspective of the stronger party in these encounters, understandably report events in a way that favours their subjects; what appears to have been a submission may in fact be closer to a negotiated settlement, and the grant of hostages for safe passage communicates that this was the case. ${ }^{57}$

Kosto exemplifies this with the episode of the Anglo Saxon Chronicle, where Olaf Tryggvason was convinced by the English king Æthelred II to meet him at Andover. Olaf received gifts and was baptised, a ceremony secured by a hostage. The hostage may in this case have been perceived as a symbolic sign of submission, as well as the baptism and the gifts. Instead of giving the I 6,000 pounds in silver that Olaf demanded, this ceremony could be carried out. According to the text, Olaf also promised not to return to England. The hostage was in fact a guarantor of a safe passage, according to Kosto, in many different cases on the continent where the symbolism surrounding hostages was important. ${ }^{8}{ }^{8}$ In this case it is not quite clear what is a description of the course of events and what is a rhetorical device. The number ' 16,000 ' is also interesting because it is close to another number that occurs in the Vita Ansgari, and could indicate 'an (indefinite) but very large amount' in the same way as other large numbers (see below).

There are examples of those who were forced to give hostages also mentioned in positive terms even if they were subjected to submission. In the Vita Ansgari, Rimbert reports about the siege of Apulia (Apuole, in present Lithuania) in Courland in 854. A Swedish king, Olof I of Sweden, carried out raids into Courland and burned Seeburg (Liepāja) before he turned to Apulia. Rimbert claims that I 5,000 'fighting men' defended the city for eight days and that there were heavy losses on both sides. On the ninth day, the Swedes were so exhausted and scared that they considered making a retreat. In their fear they could only find one resort: to cast lots to find out if their gods would help them win or if they had to retreat. After the casting, they could not understand the will 
of the gods. ${ }^{59}$ The courage left them, but among them there were merchants who reminded them of the bishops' teachings (from the mission in Sweden [Svetjud]) and advised that they should cast lots to understand the will of Christ. The lots showed that Christ was willing to help them. The Swedes were filled with fighting will and when the citydwellers saw it, they asked for negotiations for peace, something Olof granted them. The Curonians promised to give the Swedes the war booty (gold and armor) they took last year from the Danes and a pound of silver for every man in the city. They would pay the same tribute they had previously given and give hostages to show their submission and the obedience that had previously existed. Therefore, the Swedes could take a massive tribute and 30 people as hostages. ${ }^{60}$ When peace had been established between the two parties, according to Rimbert, the Swedes accepted Christ and embraced Christian traditions.

The description contains several interesting details, but in this case I will focus on some possible misconceptions, literary insertions, and learned clichés that can be found in the text. Vita Ansgari was written about 857 and meets the critical source criterion of being contemporaneous with the course of events that are described (the contemporarity criterion). However, it does not live up to the criterion of having been written in the area that is described (the proximity criterion). There may be a rhetorical maneuver in the depiction of the heathens. Two examples can illustrate this. Firstly, the casting of lots is portrayed as ineffective when it was directed towards the Swedes' own deities, and this is presented as having resulted in uncertainty and fear. However, the self-esteem was strengthened as soon as the Swedes turned to the Christian god, a topos that is common in conversion stories. ${ }^{6 \mathrm{I}}$ Secondly, some of the numbers mentioned in the chronicle can be related to numbers in both the Old Testament and the New Testament: the 30 people who would bring the tribute and the siege that was broken on the ninth day. ${ }^{62}$ When some people from the fortress volunteered as hostages it may be associated with martyrdom, in which some people sacrifice themselves for the majority, but this is only a hypothesis. It can also be a symbolic Christian fraternization, because the Swedes later declared their willingness to celebrate Easter when they were converted. 
The willingness to give hostages is emphasized rather than the subordination.

There are also some other things that can be deduced from learned insertions. The luxurious riches of gold are most likely based on ancient literary genres; insignificant, immense human masses like the I 5,000 fighting men belong to this genre as well as the presence of a 'king of the Swedes'. Such learned embroderies make it ambiguous whether the text can be used as a source of actual circumstances. But it can also reflect a syncretistic situation in which Christ is regarded as a god among others.

It should be noted that the siege of Apulia is not supported by other written sources, but an archaeological survey outside of Apuole, conducted in the I930s. The archaeologists found the remnants of a fortification; additionally there were findings of iron arrows (at least I 50). This type of arrow has also been found in the cemeteries of the town of Birka in Lake Mälaren, Sweden. They were common in Scandinavia but unusual in the eastern Baltic countries. Many of the arrows were found at the fortified wall, and some of them were broken. All the arrows were found in the same earth layer and can be dated to the ninth century. This could confirm that attacks on the fortification took place in that time. ${ }^{63}$

The above are thus examples of how the chroniclers and writers could portray the hostage in positive terms. There are also literary examples that describe how main characters have been the hostage of an enemy and how it could be turned into a triumphal flight, such as Walther in Waltharius, or revenge, as with Vikar and Starkad (Götreks saga [Gautreks Saga]; Vikarsbalkr). ${ }^{64}$

As literature, a story from the king's saga Ágrip can also be mentioned. It does not mention a hostage, but it uses the related category 'captivity'. The story is about how the three-year-old Olaf Tryggvason fled from the Orkney Islands over Sweden to Novgorod (ON Hólmgarðr). In the Baltic Sea, he is captured near the island of Saaremaa and his foster father Pórólfr is killed. But since Olaf is divinely chosen, there is a solution. An envoyee from Novgorod is at Saaremaa to collect taxes. He pays the ransom for Olaf who has been thrall for nine years. Olaf can later avenge his foster father. ${ }^{65}$ 
These examples show how the hostage situation may have been perceived as subordination because the protagonists had to cope with or master the situation they were put in after the defeat of their parents. The main characters are taken or given to the enemies as hostages when they are children or youths. These examples are found in literary genres such as skaldic poetry, legendary sagas (fornaldarsögur), and Medieval Latin poetry. As a literary theme, the state of hostage in these texts appears as something negative. However, from continental chronicle traditions there are examples of an opposite attitude towards hostages. Theoderic, who would later become 'the Great', son of Theodemir, was sent to the emperor of Constantinople as a part of a peace process when he was seven or eight years old. In the version of this event related in Getica by Jordanes, it is not quite clear who had the upper hand. Between the Ostrogoths and the Eastern Roman Empire, wars alternated with periods of peace in an area of confrontation. ${ }^{66}$

According to Getica, the Ostrogothian ruler annually sent gifts to the Emperor Marcian (d.457) to secure a peace treaty. Valamir belonging to the family-based grouping called the Amali - discovered that another grouping was in friendship bonds with the Romans, which also meant that they received annual gifts. The Amali, on the other hand, did not receive any gifts. Therefore, the Amali plundered in Illyria, whereupon the emperor softened and promised to continue the giving of gifts. As a pledge of peace, the Amali decided to send Theoderic as a hostage. ${ }^{67}$ Theoderic returned to the Amali at the age of eighteen.

Valamir's choice to send Theoderic away does not indicate submission. Rather, the transmission may had the same meaning as a symbolic, valuable gift, and can be seen in relation to Tacitus's statement that the Germans were always prefering nephews as hostages; they would have been particularly valuable. ${ }^{68}$ If the Germans perceived Theoderic as a person of great value that exceeded the gifts of the emperor, the hostage, in this case, could be understood in relation to the value of the gifts. The value of the hostage to exceed that of the gifts of the Romans and the recipient could therefore not 'pay' back, something Mauss thought of as the basic idea of the potlatch economy. ${ }^{69}$ In this way, submission was created in an interchange relationship. As seen from 
the Byzantine side, this follows a tradition that other leaders or prominent persons from areas adjacent to the Roman Empire also had experienced. ${ }^{70}$ During the final period of the Western Roman Empire, Romans also appear to have experienced this tradition when the Roman Empire was exposed to increasing pressure from opponents such as the Visigoths and Huns. As a child, the general Flavius Aetius was held as hostage by the king of the Visigoths, Alaric I (around 408), and later the warlord Uldin of the Huns. Flavius Aetius later married a highborn Gothic woman and their son, Carpilio, was sent as hostage to the Huns in $425 .{ }^{7 \mathrm{I}}$ However, it must be noted that the well-developed Roman traditions of hostages were partly different from those in the Continental Germanic areas. Nevertheless, the Scandinavian foster institution has features that correspond with Theoderic's situation.

\section{Foster children}

Procedures with foster children raised at a foreign court, like the Roman and Byzantine Empires, can be seen in the DanishContinental area of confrontations, where Danish rulers sometimes acted as enemies and sometimes as allies to the Carolingian Empire. In the early ninth century there was some Danish rulers were interested in seeking support from the Caroligians when their own realm was characterized by internal feuds. At the same time, the Danes raided the Carolingian territories or the regions of their allies.

There were in this area of confrontations instances that show that the use of hostages and the institution with foster children could be almost identical. Hemming, son of the Danish king, also called Hemming, was found at the court in Aachen in $8 \mathrm{I} 2$, according to the Royal Frankish Annals (Annales Regni Francorum), probably as a foster child (OWN fóstri). He could also have been a presumptive hostage, because his brothers Harald and Reginfred asked for peace and that Hemming should be handed out. ${ }^{72}$

A similar case is found around the character of the legendary Ogier the Dane (Da. Holger Danske) who - according to some continental chronicle traditions - became a hostage of Charlemagne. It is difficult to determine whether Ogier was a historical person 
or not. He has been identified as Ogier of Denmark (Ogier de Danemarche), or Ogier the Dane (Ogier le danois) in the Song of Roland (La Chanson de Roland), which has survived in ten manuscripts, the oldest being dated to I Iо०: the Oxford version. According to the Oxford version of the Song of Roland, Ogier has a prominent position at the court of Charlemagne. He is responsible for leading the rearguard during the retreat over the Pyrenees (stanza 748-750). ${ }^{73}$ The oldest source that is considered to confirm Ogier the Dane as a Danish great man in the Carolingian Empire is a chronicle about Olgerus, who restored the monastery St Martin in Cologne in $778 .{ }^{74} \mathrm{He}$ is refered to as dux danice. However, if Ogier was a hostage of Charlemagne, he seems, according to literary traditions, to have received some kind of 'education' as a warrior.

During the late Viking Age and early Middle Ages, when Danish rulers also became kings of England, at least one case of extradition of sons appears as something between the giving of foster sons (OI fóstri) and the use of hostages. According to the Anglo-Saxon Chronicle, Canute the Great and earl Thorkel the Tall (OI Porkell inn hávi, OE Purkyll) exchanged their respective sons in I023; Canute took Thorkel's son to England, and Thorkel kept Canute's son in Denmark. Lavelle believes that it was primarily about fostering as an institution rather than a matter of hostages. ${ }^{75}$ Here the political context should be considered. Thorkel then served Æthelred II and defended England against the invasions of Sweyn Forkbeard and Canute in IOI3. ${ }^{76}$ After the death of Sweyn, Canute withdrew from England. Thorkel also fled from the reprisals of Æthelred against the Danes. He allied himself with Canute and accompanied him to England, and after the conquest he became earl of East Anglia. But a new conflict arose between them in I02I. Canute outlawed Thorkel, who had to return to Denmark. Thorkel's tendency to take a stand against the king may well have played a role for the status of his son, but that is a hypothesis; we have no further information in this case. ${ }^{77}$

Another demanding settlement involving a foster person - who practically functioned as a hostage - can be seen in Heimskringla's version of the Saga of St. Olaf (Óláfs saga helga), which generally runs parallel to the probably older Orkneyinga saga, dating back 
to about II90. The saga describes how Olaf Haraldsson had a few confrontations with the earls of the Orkney Islands and the Shetland Islands. ${ }^{78}$ The confrontations consisted mostly of negotiations, alternating with threats by the king, whereupon some of the earls restored the settlement with the king as much as possible. ${ }^{79}$ They had previously reached an agreement with the King of the Scots and have contended among themselves. Olaf could claim the Orkney Islands with reference to the fact that Norwegian kings had previously landed there, and therefore he regarded them as his inheritance. ${ }^{80}$ Some of the earls chose to unite with Olaf, but especially the earl Thorfinn Sigurdsson (ON Porfinnr Sigurðsson) resisted. Earl Brusi Sigurdsson (ON Brusi Sigurðsson), brother of Thorfinn, chose to ally with Olaf. Thorfinn had supported his grandfather, the Scottish king, but his territory was only one third of the islands, while Brusi had two thirds and Thorfinn wanted half of the islands. ${ }^{81}$

The two earls participated in things and other meetings as their friends tried to reconcile them. Then Brusi, who was the weaker, paid a visit to King Olaf with his ten-year-old son Rögnvald (ON Regnvald Brusason). Brusi offered the king his friendship. The king set the condition that Brusi would be his henchman, but at the same time he gave him the isles as bestowment. Unless Brusi agreed to this agreement, the king required the properties on the islands that his ancestors and predecesors previously possessed. The earl agreed to the settlement after having consulted with his friends. ${ }^{82}$

The earl became the king's henchman (handgenginn) and the agreement was confirmed with oaths. Later, the king made the deal that Brusi was to have two thirds of the Orkney Islands, but to bound him as his henchman, he took Rögnvald as hostage. Rögnvald was attributed with positive qualities in the Orkneyinga saga:

Hann var allra manna fríðastr, hárit mikit ok gult sem silki. Hann var snimma mikill ok sterkr. Manna var hann gørviligastr bæði fyrir vits sakir ok kurteisi. Hann var lengi síðan með Óláfi konungi. ${ }^{83}$

Rognvald [sic] was one of the handsomest of men, with a fine head of golden hair, smooth as silk. At an early age he grew to be 
tall and strong, earning a great reputation for his shrewdness and courtesy, and he stayed on with king Olaf for a long time. ${ }^{84}$

(Transl. Hermann Pálsson \& Paul Edwards)

Naturally, he received these positive qualities when he lived with the holiest of all the kings of Norway.

It could be difficult to understand Olaf's actions - whether these took place in reality - filtered through Snorri's elucidation. Snorri points out that Olaf understood how Brusi was somewhat unhappy with his actions: 'at Brusi gekk tregliga at ollu sáttmálli, en moelti pat eina um, er hann oetlaði sér at halda (that Brusi went slowly to all the negotiations, but never gave promises that he would keep)', but the text is similar in the Orkneyinga saga. ${ }^{85}$ Thorfinn willingly makes an agreement with Olaf, who, on the other hand, suspects Thorfinn of making changes to the deal. Thorfinn has the stronger military on the islands through his grandfather's support. ${ }^{86}$ Perhaps Olaf wanted to take Rögnvald as hostage to assure the full support of Brusi so that he would not become a turncoat. The hostage does not appear in this case as a word but with a euphemism: '[...] ek vil festa trúnað með pvi, at ek vil hér sé eptir með Rognvaldr, sonr pinn (I will bind your faithfulness to me by looking after Rögnvald, your son)' ${ }^{87}$ The text does not mention whether Rögnvald is a foster son, but implicity it seems to be the case. The hostage was a tool that hade been used in the areas of confrontation between the Orkney Islands and the Norwegian Kingdom ever earlier, e.g. when Hunde became a hostage of Olaf Tryggvasson (see below).

It is also interesting that Olaf, according to the texts, always refers to the actions of his ancestors regarding his power ambitions on the islands. By such means of power legitimation, the traditions of hostage were formed in this context. But in this case, we are dependent on the versions of Heimskringla and the Orkneyinga saga; no skaldic poems mention anything about the hostage. Nevertheless, it is mentioned by Sigvat the Skald (Sigvatr Pórðarson) in his drapa of the death of Olaf that Olaf used hostage as an instrument of power to control chieftains in Norway. In another drapa, by the skald Óttarr the Black (Óttarr svarti), it is 
mentioned that he landed on the Shetland Islands (Hjaltland) and the Western islands (eyjum vestan) ${ }^{88}$

\section{Foster children in Iceland}

In Iceland, there seems to have been a type of institution with foster children that concerned families and their friendship instead of the regulation of major areas such as kingdoms (see the introduction). The historian Ian Miller has described the foster institution as it is reproduced in the Icelandic genealogies. He points out that children could be a burden: they were costly, and it took time and effort to raise them, something that could have been an underlying factor in why foster parents sometimes undertook their care ${ }^{89} \mathrm{He}$ divides foster parents into three groups based on their rank:

(I) If the recipients were of a lower grade, they could be forced to commit themselves by fostering a child.

(2) If the recipients were of an equal rank as the donors, the receipt of the foster child was a way of bridging conflicts.

(3) There may have been an obligation to receive someone within a family-based grouping that may have brought an advantage through the fact that the foster children grew up in a wealthier household. This meant that the children were taken care of by a servant or the equivalent from the great man's own estate. ${ }^{\circ}$

In some cases, those who gave away their children as foster children were superior to the recipients, while in other cases they seemed to have been the opposite. According to Miller, there were several binding mechanisms within the foster institution that could take place at one and the same time, involving several exchanges between relatives. Sometimes sons were sent only to preserve the peace of a household, a way to get rid of 'messy children' or to protect young women from men's interests. ${ }^{9 \mathrm{I}}$

Another variant was that children could have a foster parent from their own home that was responsible for their education..$^{92}$ Thus, there was a complex social fabric with many different varieties of 
fostering in the Old Icelandic society. On the other hand, foster children were never intended to be hostages as Miller puts it:

In each of these instances the offer was an act of kindness, of reconciliation; but at another level, the child also looked a little like hostage to secure the maintenance of a nervous peace. [...] In fact no evidence in the sagas indicates that such children were perceived as hostages. There are no examples of a foster-parent threatening to harm the child, nor any instances of natural parents acting out of fear of what a foster-parent might do to the child. The [foster] children, it seems, were treated no differently than any other child would have been. ${ }^{93}$

I agree in part with Miller. As previously mentioned, it is not possible, based on the analysis I made of conflicts mentioned in the Íslendingabók and the Landnámabók, to claim that hostage was used as an instrument of power in conflicts and peace processes between individuals and groupings in the Old Icelandic society. But it occurred in at least a few cases between the Icelanders and the Norwegian royal power. One case was when Kjartan Olafsson (ON Kjartan Ólafsson) and a few Icelanders became hostages at the court of Olaf Tryggvason in 999, which is described in Laxdola saga. ${ }^{94}$ Another case was when the great man Jón Snorrason was held hostage by the king Håkon IV Håkonsson (ON Hákon Hákonarson) in I22I, when Iceland was subdued by the royal power. ${ }^{95}$

Miller's motivation for his claim that a hostage did not appear as a foster child is vague because he relies only on Old Icelandic texts. It may be that hostages in other contexts are not mentioned with words, and there may have been variants where it is not possible to distinguish a pattern with sharp dividing lines between hostages and foster children. It can be noted that Miller does not completely reject the possibility that the foster institution held up a fragile peace as a binding mechanism. With Miller's reasoning, the foster institution could thus have acted as a stabilizing factor for peace in its own right, and the foster child could have been more than just "a little like a hostage" ${ }_{96}$

The historian Auður Magnúsdóttir has a different view of the foster institution in the medieval Icelandic society than Miller. Auður argues that foster children could only be part of a subordination 
because they were given and thus represented a vertically oriented action. According to Auður, the foster institution was therefore a stronger binding mechanism than relying on biological family bonds, because through this confidence, subordinate householders could maintain their loyalty to their superior great men. ${ }^{97}$

Auður's reasoning could, in part, explain the absence of hostages - despite the similarity with the foster institution - in Iceland during the Viking Age and the Middle Ages. The foster institution became vertical with the establishment of the great families, or groupings, during the Middle Ages..$^{8}$ This means that during previous periods the foster institution could have been horizontally oriented, used between householders that were more equal. Perhaps later, a vertically directed foster institution became sufficient to control underlying territories in the immediate vicinity of these dominating groupings.

The hostage, on the other hand, was, generally both horizontally and vertically oriented. That the use of hostages did not occur in the Old Icelandic society during these periods when war and peace shifted may have been due to the size of the individual households. In other cases, in Scandinavia, there was competitiveness between great men and rulers with the ambition to control a kingdom or a region. The longer the distances and larger the areas, the more likely that the 'real' hostage could be used as a regulating factor. This can partly confirm my hypothesis that hostages in peace processes in Iceland only began to be used once the territorial division became clearer. It can also be compared to Jón Viðar Sigurðsson's hypothesis about the island communities of northmen as more 'peaceful' and collaborative. 99

The above example shows that there are cases where the giving of hostages is not only associated with a symbolic submission, although several examples indicate this. Thus, the hostage was not only part of arrangements of superiors and subordinates, but also it was done in a complex manner, with geographical and temporal variations. To this could be added the different views of writers and chronologists on the degree of submission.

There is no unambiguous picture of hostages as subordinate in the Old Icelandic litterature. As an institution within the 
Scandinavian countries, it was corrected by varying legal, religious, political, and social circumstances. One could summarize the conditions as follows:

(A) There was some confusion about who was to be counted as hostage, by continental chroniclers and Nordic writers.

(B) Geographical distances contributed to the confusion.

(C) It is difficult to see hostage merely as 'pure submission', even if that type occurred.

(D) Gift-giving conditions could occur between equal parties.

(E) Political considerations in it was important to keep in with one's opponents which could be some of the reasons for taking and giving hostages.

(F) 'Investments' for future alliances was another reason for hostage exchanges.

(G) The difference between foster children and hostages was in some cases difficult to discern in Scandinavia.

In the case of A, C, and D, it is almost exclusively about a foster institution. A and D were not necessarily about warlike conditions but could apply to steps two and three according to my model, where one gradually tries to ease the tensions at the same time as unrest could threaten to erupt again.

\section{Conduct and loyalty}

The conduct of the hostage had consequences in much larger contexts than that of the 'guest' of the nobility who could seek exile and protection of his or her own choice. A person who was a hostage was in a more vulnerable position - where others made the decisions - but it could also be a matter for the hostage to show loyalty toward the hostage taker, and the taker must have been bestowed with certain responsibilities.

\section{Cases with 'trust'}

I have previously pointed out how the social bonds must be actively maintained through actions associated with the foster institution. 
It is comparable to Lavelle's idea that hostages in some cases had to prove their loyalty symbolically. ${ }^{100} \mathrm{He}$ gives examples of how a hostage of the Anglo-Saxons shot an arrow against the Viking army during the Battle of Maeldun, in Essex in 99I. It was Escfrith, son of Ecglaf, who showed his loyalty to Earl Byrhtnoth and the AngloSaxons in this way.

Kosto mentions a similar example from the Anglo-Saxon Chronicle. It concerns an Anglo-Saxon (Welsh) hostage who was the only survivor after an attack by Cyneheard on King Cynewulf of Wessex. ${ }^{\text {Ior }}$ Obviously, the Welsh hostage fought on Cynewulf's side because he was severely injured. In both cases, it is not a standpoint against its own side. However, the symbolic significance of the action should not be undersestimated.

In Continental Germanic traditions, hostages fighting for their recipients are a recurring theme, but they are literary works that can possibly build on oral traditions. In the Waltharius poem (first half of the I I th century), for example, three Frankish and Germanic kings were forced to hand over hostages and some treasures to Attila to avoid invasion. ${ }^{\mathrm{I} 2}$ As a result, Walther (Waltharius), a son of a Frankish king, grows up at the court of Attila, battles on his side, and eventually becomes almost an honored son. He flees together with the princess Hiltgund, a Burgundian hostage, and takes some treasures with him. The story can be interpreted as Walther restoring some of his lost glory in the form of the stolen treasure and the rescue of Hiltgund.

There are some possible parallels to this behaviour, even in Old Norse literature, for example in Gautreks saga in which King Vikar (OI Vikarr) and other sons of great men become hostage to King Herthjóf (OI Herpjofr) of Hordaland, Norway. ${ }^{103}$ Vikar was raised at Herthjóf's household and seemed to be treated well. For example, he got the confidence to guard a beacon. But because Herthjof killed Vikar's father, he must avenge this, and he did, together with his foster brother, Starkad (ON Starkaðr), who was raised parallel at the island of Fenhring (present Askøy outside city of Bergen) by Hrosshársgrani (a name of Odin).

These texts also testify to ambivalence because they depict rebellion against the hostage taker. Walther, like Vikar, broke up with their hostage takers. There might be a moral issue in these stories; 
the confidence can suddenly be broken in the case of former enemies, even if it is implicit in these texts. Nevertheless, trusts were important for both symbolic and pragmatic reasons. Hypothetically, the reason for such confidence could be that it involved functions primarily in the household, including different constellations of companionship. Loyalty attached to the close sphere became at least initially easier to control than outside that sphere.

From the point of view of the hostage taker, the presence of the hostage may indicate his status. The tradition is best known from Old Irish contexts: 'he is not king who has hostages in fetters'. ${ }^{104}$ Whether or not this symbolic approach was expressed in Old English, Continental Germanic, or Old Norse traditions, we do not know. However, as both Lavelle and Kosto emphasize, the hostage also deals with reciprocity, i.e. the hostage was in several cases given, not only taken. ${ }^{\text {Ios }}$ In such a constellation, it may have been important not only to symbolically manifest the subordination but also the loyalty: the guarantor's obligations towards the hostage.

In Old Western Norse sources, perhaps the clearest expression of a possible symbolic, subordinate relationship is in Sigvat the Skald's drapa of St. Olaf. In the poem it is said that it is 'wise' to provide hostage to Olaf Haraldsson. In this case, there are subversive 'kings' in the conquered county; it is a political situation that is in line with the first step in my model with the establishment of social relations, but perhaps, in this case, does not reflect a reality. To provide hostages in this context can nevertheless also be interpreted as an opportunity to secure peaceful relationships. A situation like this might have been a reason for good behaviour: the hostage would secure its position by proving its loyalty and thus securing future good relationships and alliances, regardless of the deprivation of the recipient side. Some unambiguous explanation for the trust hostage received in exchange for loyalty and good conduct is not possible to give; these situations were probably due to both the political situation as well as purely individual.

\section{Female hostages}

As previously mentioned, researchers like Kosto have claimed that women who were handed out would primarily become wives. If 
it were common in Continental Germanic contexts that future brides were given to a possible enemy, it is likely that this custom occurred in Scandinavia too, although, as far as I know, there are no texts that explicitly use the word 'hostage' for a bride (or potential bride). Therefore it is interesting to compare the functions of married and unmarried women before a regular wedding. For example, was a bride price given, or a dowry, in these contexts as a part of peace processes? In my view, however, it is a reductionist approach to assume that women would only have functions related to marriage. Perhaps such functions must primarily be derived from Old English or Continental Germanic, contexts. In Scandinavian contexts, there were several functions for women. For example, according to the historian Michael Enright, the queen Weolbeow had a 'warden role' connected to the peace in the mead-hall Heorot, which prevented the fighting between men. ${ }^{\text {106 }}$

If women possessed certain functions before marriage, captivity, or hostageship, these functions could be transferred to the new household. In such cases, these functions can be related to the traditions of the non-Christian Scandinavian societies that did not necessarily fit into the values of Christian writers and chroniclers. Some of these traditions can be related to war and peace. They can therefore be compared to how the functions of women could be linked to a symbolic capital in a similar manner to the men who became hostages.

In Scandinavia and Iceland, some women - including wealthy widows - had a special social value. We know that some widows had specific functions that could be related to, among other things, the functions of the godar on Iceland, which is an additional aspect of women's social value for peaceful solutions of war and other conflicts. Aud the Deep-Minded (ON Auðr djúpúðga) in the Laxdoela saga held ceremonial banquets and ruled over both her own farm and other subordinate units. ${ }^{107}$ These honorable women could themselves have affected the outcome of conflicts with more indirect instruments than men.

A woman who was married into a new household may have contributed with new knowledge and other social capital in the environment of the foreign hall and in other areas of communication 
that she now took part in. For example, Hildeburh in the Beowulf epic organized the pyre of her son, her brother Hnæf, and her husband Finn, which could be compared to the role of Weolpeow in the mead-hall. ${ }^{108}$ The ritual act can be interpreted as an attempt to create new bonds during the peace that followed; it became a way to reconcile symbolically.

Continental Germanic literature mentions other types of functions. Hiltgund becomes treasurer and is tasked with managing Attila's treasury. ${ }^{109}$ It could be a literary, stylistic feature freely based on old traditions; still, one could compare this with the married woman's situation in the Old Scandinavian society: she brought the dowry to her new home and took custody of it.

The above examples can be compared with Kershaw's hypothesis about the situation of the male hostage arriving to the new home:

The contrast with male hostage is noteworthy: men in foreign households were acculturated, women in foreign households were agents of culture. For royal women seeking to foster peace under their own initiative and free from a male-dominated framework a further strategy was available: prayer, either their own or the formal commissioning of prayers for peace from religious communities, an approach favoured by both Radegund and Balthild in the later seventh century according to their biographers. ${ }^{\text {I }}$ o

Kershaw's examples primarily concern women in Continental Germanic and Anglo-Saxon socities. The married woman in the Old Scandinavian society had primarily cultural functions attached to the home and the cult buildings. In Old Western Norse sources there are some hints that women also had other cultural functions, including some that could be related to war and peace.

\section{Women and the thing}

In some research, Scandinavian women have been considered excluded from the thing, an area of communication where decisions about war and peace were made. Recently, the archaeologist Alexandra Sanmark has problematised the image of women's role in relation to the assemblies. Contextual differences appear to have existed between the Norwegian and Icelandic things. 
Sanmark, who relies on the Icelandic law Grágás and Norwegian medieval laws, describes five different 'scenarios' that existed in Norway and by which women could approach the thing: III

(I) Women inherited after the death of other family members (husband, child).

(2) Baugrýgr, 'ring woman', an unmarried woman who inherited both land and esatates and had no close male relatives.

(3) In the event of a conflict between women, only women could claim compensation for the matter at the thing.

(4) Warden of a household.

(5) Female witnesses at the thing.

It appears that women, according to these scenarios, were entitled to conduct negotiations at the thing. In Norway, the ring women could inherit (additional) manors and receive fines. The fourth group could act on the thing on behalf of their men if they were unavailable. Sanmark points out with reference to Else Mundal that female witnesses could testify in almost all kinds of cases, not only in special circumstances such as murder cases. ${ }^{\mathrm{II} 2}$ The same rights for women are not found in the Icelandic laws, even though the degree of their freedom there was higher than has been assumed. ${ }^{\text {II3 }}$

Sanmark's hypothesis about women's ability to influence political outcomes at the things can be compared to my own model: there were different ways to mediate messages of reconciliation in the areas of confrontation. If women had these opportunities, they could certainly have influenced the outcome of peace processes in other arenas than in the above-discussed hall environment.

I have mentioned that women who were in hostage-like situations could (a) have been that directly after a peace process or a war campaign, or (b) have been given as a wife (implictly as hostage). They may also (c) have become wives after a period as fóstra, 'foster daughter' (see later section). Did these women have the same rights as in 'normal' marriages? There is nothing that contradicts certain restrictions due to the conditions regarding the marriage. This can be seen, for example, with women with some form of restricted degrees of freedom such as the thrall Melkorka in Laxdoela saga, 
who is originally captured in Ireland. She became mistress (ON. frilla) of the chieftain Hoskuld (OI Hoskuldr Dala-Kollsson) and was then driven away from his household by his wife. As expressed in the Laxdoela saga, Melkorka had privileges that imply a free position. She received a new estate as a gift from Hoskuld: Melkorkastead (OI Melkórkustaðir). Later she married Thorbjorn Skrjup (OI Porbjorn skrjúp). ${ }^{\mathrm{II}}$

In Sturlubók's version of Landnámbók, king Hjörr of Hordaland (ON Hörðaland) raided Bjarmaland and took Ljufvina, daughter of the king of the Bjarmians, as a prisoner of war (herfenginn). She gave birth to two sons of Hjörr. They were dark-skinned and were given the names Geirmund (OI Geirmundr) and Hamund (OI Hamundr). Ljufvina replaced them with the children of a female thrall because they were fair-skinned. Even here, it seems to be descent rather than privileges that matter as in the case of Melkorka, who is described as the daughter of an Irish king, Myrkjartan (OI Muirchertach). Nevertheless, the text still suggests that Ljufvina acted as the wife of Hjörr and was called 'Queen'. ${ }^{\text {II }}$

\section{Women as cult leaders}

According to Sanmark, women were important as cult leaders, and she points out the connection between the cult and the things, something which supports the assumption that women participated in 'assembly rituals'. ${ }^{116}$ As cult leaders, they may have presented warlike messages. This suggests that they may also have had other types of functions that made them valuable as hostages. To further understand how women functioned symbolically in connection with war, we must turn to ancient texts.

The relationship between men and women as cult performers could be exemplified by a narrative in the Commentaries on the Gallic War by Caesar. The Romans had confrontations, which included both talks and battles, with the ruler of the Suebi, Ariovistus. Caesar claims that the Suebi did not show up in the morning during the decisive battle. He then withdrew his troops to the camp. At noon, Ariovistus attacked the camp and retreated at sunset. Caesar asked the prisoners why the Suebi did not attack at dawn and was told that the married women read whether the 
battle would go wrong or not through rituals of divination. The women said that it was the will of the gods that the Suebi would not battle until full moon. ${ }^{117}$ This story may be due to Ceasar's political ambition and not fully reliable.

Veleda, a seeress of the Germanic tribe Bructeri, was an important political player in the Roman-Germanic conflicts. Veleda seems to have exerted a great political influence on German tribes. Tacitus mentions that she was worshiped as a goddess by some. ${ }^{\text {II } 8}$ With her, political and cultural functions coincided. Among other things, she played a crucial role during the Revolt of the Batavi in 69-70 AD. She stood in a tower from where she spoke to the insurgents, answering questions about the outcome of the war. According to the poet Statius, Veleda was captured by the Roman general Callicus. ${ }^{19}$ From neither Tacitus nor Statius is it apparent how the Romans treated Veleda during captivity, but it was symbolically important that they held her as a prisoner, or as presumptive hostage, which is evident from Statius's text.

Veleda has been compared with the Old Scandianvian volur. ${ }^{\mathrm{I20}}$ Sundqvist and the historian of religions Catharina Raudvere has pointed out that the seiðr, 'witchcraft, sorcery', was performed when they ambulated between different places. ${ }^{\text {I2I }}$ This is one of the reasons why the texts describe the volur as 'strange' or 'exotic'. They are described in the Old Western Norse literature as deviant in terms of age, sex, and geographical location. Their functions can be related to war and crisis, and because they could behave in aristocratic environments, they may have been actors with purposes that are not always harmonised with the will of the great men. ${ }^{\text {I22 }}$

Women of other social belongings than the volur also had cultic functions during war- and peace-setting contexts, and it may be of interest to examine some of the sources. Outside the text material, a few motifs on Gothic picture stones can confirm that women had cultic functions related to both war and peace.

The importance of ceremonial toasts has previously been mentioned. The historian Agneta Ney has analysed women in the Iron Age society of Gotland and compared motives on picture stones representing a woman who is giving a drinking horn to a man, sometimes sitting on a horse, with the description of the queen Weolhpeow in the Beowulf epic. ${ }^{123}$ 


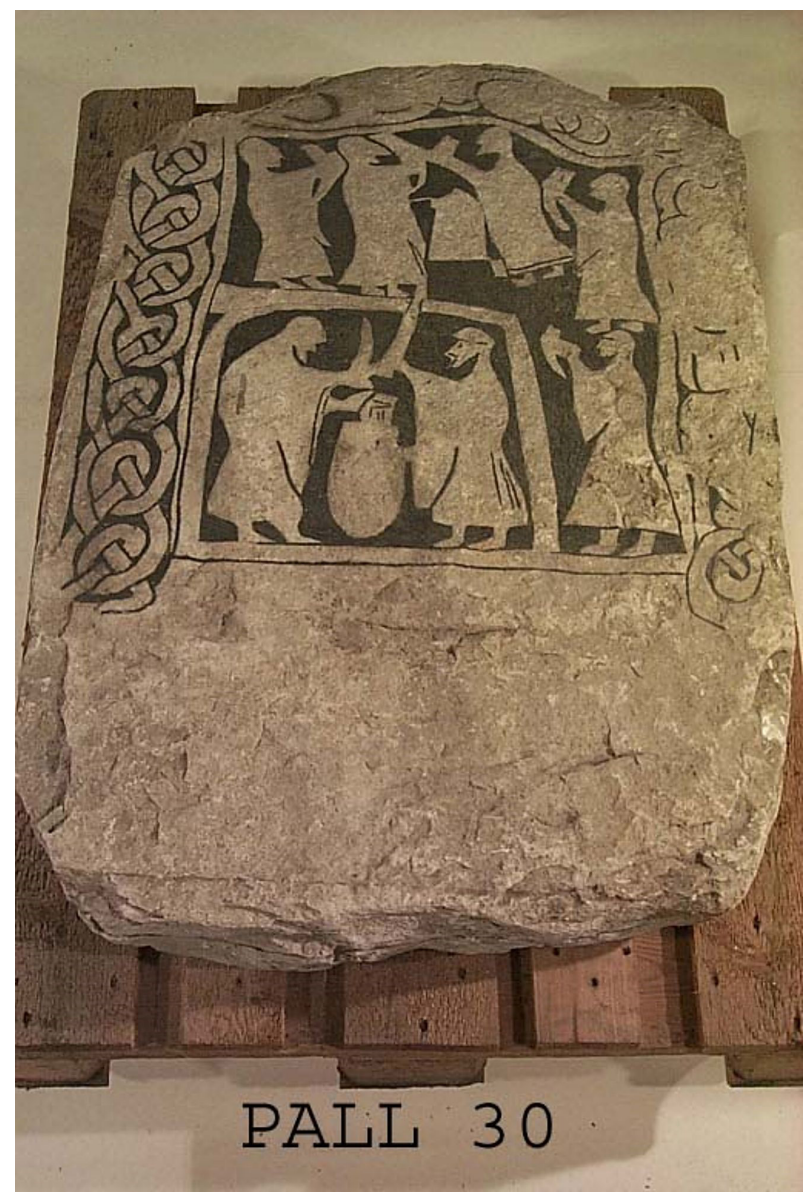

Figure IV.1. Picture stone from Lärbo (Gotland), Tängelgårda IV, which may depict a libation. Source and copyriht: Photo: Ola Myrin, The Swedish History Museum. License: CC BY 4.O.

The picture stone from Lärbo (Figure IV.I), Tängelgårda parish in Gotland, shows that the subject with horn that is given is not only found in literary contexts. Furthermore, this ceremony does not appear to have taken place in the hall but also outdoors, as can be seen on this picture stone from Lärbo. At the same time, the picture stones do not necessarily represent women in peaceful contexts. On some stones, women are depicted as in warlike situations, 


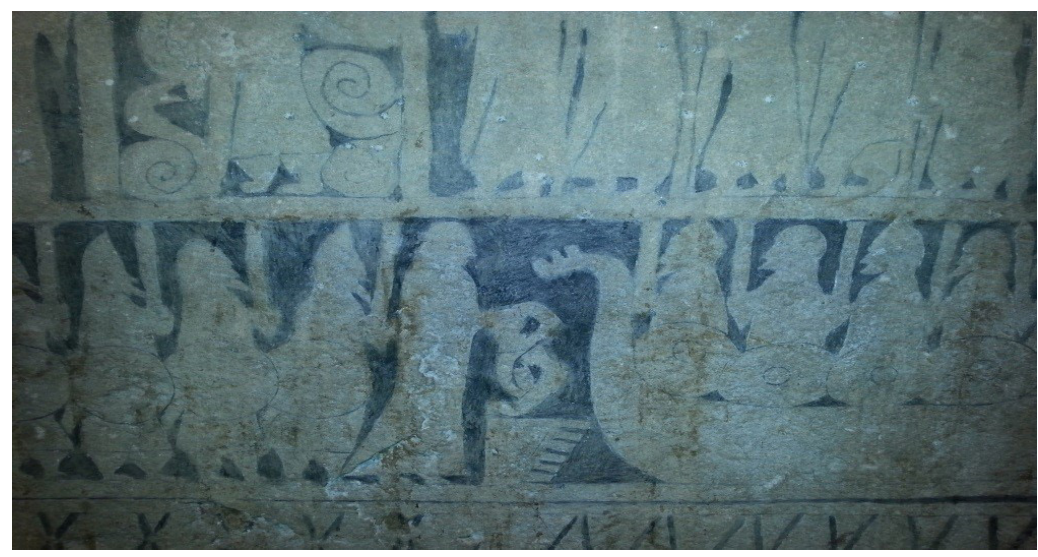

Figure IV.2. Picture stone from the church of Smiss, Gotland, dated to to the eighth century. The motif could be a woman who performs a sacrificial act with a worm. Photo: Stefan Olsson.

for example on the motif on the stone from the church of Smiss (Figure IV.2). This motif has by several researchers, including the folklorist Aðalheiður Gudmundsdóttir, been linked to the the being called Hild (ON Hildr) in the legendary battle Hjaðingavíg, where she resurrects fallen warriors. Apart from the parallel from the legend, we can identify some cult objects on the picture stone. The woman holds what seems to be a snake in her hand, an animal that has been associated with Odin and perhaps with war. ${ }^{124}$ The woman leans over what appears to be an altar (ON stallr, stalli, or possibly a hörgr). Swords, ships, helmets, and shields may not be interpreted as individual cult objects but appear in this case to be associated with warlike activities. The men move into what seems to be a procession. Clearly, the picture is depicting a warlike situation with a woman in a leading position.

Aðalheiður believes that the Hjaðingavíg in its ancient Scandinavian versions reflects the wish of men to be healed after their death on the battlefield (as in the myth of Valhall and the einherjar). Thus, it could be a symbol of women's reaction to the destructive forces of warlike societies and a desire to restore society. ${ }^{\mathrm{I} 25} \mathrm{By}$ assuming this type of role, women could take the consequences of men's mistakes. 
Other sources implictly suggest that women had functions during political negotiations where a hostage was a resource. Knytlinge saga contains a story about Emma, the wife of Canute the Great. Canute was married in IoI6 to the widow Queen Emma of Normandy, who had her sons, Edward and Alfred, with Ethelred II of England. ${ }^{\mathrm{I} 26}$ According to the much earlier Encomium Emmoe Reginae (probably written in IO4I), Emma cunningly refused to become the bride of Canute unless he promised to not appoint the son of any other woman as heir to the throne. Canute accepted the terms and took an oath to not appoint any other son than the children of him and Emma. Thus Emma made arrangements for her offspring. The Encomium further reports that the marriage of Canute and Emma ended the ongoing war with the English king Edmund Ironside (who passed away the same year). ${ }^{\mathrm{I} 27}$ Later Emma gave birth to Harthacnut who became the heir of Canute.

According to the Knytlinge saga, the sons of Emma opposed Canute, who made a siege on London, which was held by the sons. Both sides sent emissaries for negotiations, hostages were given, and a truce was signed to more confidently discuss the negotiations. ${ }^{\mathrm{I} 28}$ Did Emma have an impact on these negotiations because she had close connections to both sides? The accuracy of this information must be regarded as unclear because the Knytlinge saga was written in the mid $\mathrm{I} 3$ th century. According to the Icelandic philologist Ármann Jakobsson the general tendency of the saga is 'the institution of kingship as such, and with the virtues of kings', some of these kings and good others evil. ${ }^{29}$ The conflict with the sons are not mentioned in the Encomium, which only reports that the sons of Emma and Canute was jointly sent to France while Harthacnut was kept in England. ${ }^{130}$ Was this a way to avoid conflict? Still, the example might illustrate how a woman could have an intermediate position that could be decisive for the outcome of the peace, or war, even if it was directly or indirectly through a council as it is implied by the Encomium.

\section{Gunnhild}

One of the few named Scandinavian women who can be identified as hostage is Gunnhild who lived in the early i ith century. 
She belonged to the Danish royal family because she was sister of Sweyn Forkbeard. She was probably married to the chieftain Pallig Tokesen, who served with Æthelred II in England. On the I 3 th of November in I002, she was supposedly executed in the so-called St Brice's Day massakre. Ethelred II had all the Danes he could find executed. According to the historian Ann Williams, the objective was probably to wipe out the Danes who were in the service of Æthelred and not the Anglo-Saxons with Danish ancestry in the shires. The Vikings, who were divided into different groupings, were considered false and prone to betrayal. ${ }^{\mathrm{I} 3 \mathrm{I}}$

The 'St. Brice's Day massakre' is reported in the Anglo-Saxon Chronicle, but neither Gunnhild nor Pallig is mentioned. Much suggests that the 'St. Brice's Day massakre' is a late construction because it is only mentioned in medieval chronicles. William of Malmesbury has the most information about Gunnhild (or Gunnhilda). According to him, Gunnhild, together with her husband, voluntarily entered the hostageship as guarantor of an Anglo-Danish peace. ${ }^{132}$ The motif - that they would have volunteered as hostages - could be compared with the previously mentioned hypothesis that hostages could be acquired because they were valuable persons. In any case, one cannot assume that Gunnhild alone took this decision.

William of Malmesbury describes Gunnhild as 'beautiful'. When she came to England, she converted to Christianity. When she was killed, she behaved with 'courage' and did not lose her beauty even after she was killed, William writes. ${ }^{133}$ This is in line with the cliché image William gives of historical women: primarily as non-violent, beautiful, virtuous, and with good mental qualities, something comparable to female characteristics as they are presented in other types of source material.

\section{Female warriors}

Whether female warriors ever existed in Scandinavia is a muchdebated issue. Researchers including the archaeologist Neil Price, the historian of religions Britt-Mari Näsström, and the historian Agneta Ney argue that some women acted as warriors. ${ }^{\mathrm{I} 34}$ There is, however, weak support for this in text sources such as 
Gesta Danorum (Book 9), where it is told that the evil king Frø of Uppsala put women of noble lineage into a brothel. The hero Ragnar Lodbrok (ON Ragnarr Loðbrók) attacks Frø and is aided by the female warrior, 'shieldmaiden', Lagertha (ON Hlaðgerðr), who fights with 'locks flowing loose over her shoulders'. ${ }^{\text {335 }}$ Näsström points out that an inspiration for Saxo Grammaticus could have been the Catholic virgin martyrs that flourished in the fourth century. In the hagiographical, these martyrs try to keep their virtue sometimes by fighting like Thekla, a follower of Paul, who fought in the Amphitheatres. ${ }^{136}$ Other sources, such as the Gesta Hammaburgensis Ecclesiae Pontificum by Adam of Bremen, report of 'amazons' in the heathen Scandinavian societies. This kind of information must be regarded as fiction; it was a common theme in literature from the seventh century onward to describe female warriors and huntresses. ${ }^{\mathrm{I} 37}$

Recent archaeological findings and reinterpretation of earlier findings have reignited the debate on female warriors. An investigation of a warrior grave $(\mathrm{Bj} 58 \mathrm{I})$ at the island of Birka, in Lake Mälaren, showed that it contained a presumed male skeleton and the equipment of warrior: a sword, an axe, a spear, armourpiercing arrows, a battle knife, two shields, and two horses. A recent analysis of the genome-wide sequence data showed that it was not a man but a woman that was buried. The woman was probably not of Birka origin. According to Hedenstierna-Jonson et al., this is proof of not only a female warrior but also a female war-leader. ${ }^{138}$ In addition, findings from Norway may also be interpreted as burials of female warriors. At the farm Nordre Kjølen in Trøndelag, a mound was excavated in I900 where grave goods such as a sword, axe, spear, shield, and arrows, and a skeleton of a horse were found together with a skeleton of a woman.

In spite of these findings one must be careful to conclude that it was a question about female warriors. The archaeologist FransArne H. Stylegar points out that the findings were made in the I 9 th and early 2oth centuries and circumstances were not ultimate; for example, in the Norweigian case it could be a double burial, with a man and a woman. The women may not have used the weapons actively in life. ${ }^{139}$ The archaeologist Leszek Gardeła examined the funerary material of some burials with possible 
remnants of female warriors. According to Gardela, there is proof for the existence of female burials with weapons. ${ }^{\text {I40 }}$ The most common weapon types for these burials were axes, which is troublesome because these items functioned not only as weapons but also as tools. Gardela concludes that we cannot be sure whether women used the weapons that they were buried with and that the interpretation of the burials must follow the contextual circumstances. $^{\text {IrI }}$ Nonetheless, the reinterpretion of these old findings adds fuel to the ongoing discussion.

If there ever were female warriors they would certainly be suitable as hostages.

Although it is not possible to see a unique pattern of the role of women, their qualities and abilities, their social capital, that the texts support, they seem to have had important functions in times of war as well as times of peace. These functions could be compared to the multifaceted functions that male hostage seems to have had. One problem to be aware of is the Christian influence in that kind of context. These sources are also tendentious by describing events in different times and areas. Nevertheless, it can be concluded that women in the cultures described in the sources did not have one but several functions in addition to being a wife in a household. In this way, women became important actors in negotiations, among other things. Thus, the above mentioned examples could illustrate some of the reasons that women became hostages.

\section{The unsuccessful agreement}

Although oaths were taken and hostages given in bilateral agreements, sometimes peace agreements failed. For example, such failures can be seen in the Royal Frankish Annals for the years 8०4, 8०8, 8०9, and 810. ${ }^{\mathrm{I} 42}$ The Danish king Godfred (or Gudfred) arrived at the border area between South Jutland and Friesland in 804 and exchanged messengers with Charlemagne. Godfred made a peace agreement, a personal settlement, with Charlemagne, but in 808 he attacked the Obotrites, according to the Royal Annals. The following year, Charlemagne's emissaries failed to negotiate 
a peace. In 8 Io Godfred assaulted the coasts of the Frisians and forced the householders to pay roo pounds in silver. ${ }^{143}$

In this type of failed peace process, hostages sometimes appear to have had restrictions on personal freedom, something that may have been perceived as extremely offensive to those who came from the upper strata of society. The hostage may also have become a pawn in a political game between the various groupings in which the loyalty of the hostage was not always clear. It could also be the ultimate destiny of the hostage to be executed or die far away from relatives and friends. An example of this is found in a story in the Orkneyinga saga. According to the story, Olaf Tryggvason arrives to the Orkney Islands. There he encounters earl Sigurd Hlodvirsson (OI Sigurðr Hlöðvisson jarl) and demands that he and his people accept Christianity. Sigurd wishes to obey Olaf, who then takes Sigurd's son Hunde (OI Hundr), or Whelp (OI Hvalpr), as hostage. Hunde is baptized and Olaf gives him the name Hlaudvir (or Hlodvir). When Olaf returns to Norway, he brings Hlaudvir, who lived there for only a short while until he died. After the death of Hlaudvir, Sigurd no longer feels bound to his promises to Olaf. In this case, the hostage had played its part. Whether Hunde died a natural death is not apparent from the text, though it is likely.

The above examples lead to questions: Which restrictions were imposed on a hostage? Did violence occur, and in such cases, why? These are themes we shall turn to in the next sections.

\section{Unviolable hostage?}

A hostage was never completely without rights, but these must be seen in relation to the current circumstances as well as the political and religious contexts. There were various reasons why hostages were violated. They were due to the degree of the protection that was stipulated. If the hostages were violated, it could have to do with how the relationship was percieved by the taking side. Misconceptions and suspicion may have arisen during the course of events. Another possible reason for the hostage being treated badly - as mentioned earlier in the discussion of the foster 
institution - may have been that they became a financial burden: a person from the upper strata needed an expensive support.

In the Roman Empire there were apparently hostages who were protected by the written treaty and the hostage takers were obliged to ensure that they were not violated. According to the legal historian Stephan Elbern, the treaty (foedus) ensured that hostage (in some cases) even became 'sacrosanct'. ${ }^{\text {I44 }}$ Elbern does not explain the concept of 'sacrosanct' but suggests that the hostage had connections with religious traditions.

Elbern's position has been discussed by Walker, who argues that in the Roman Empire it was the design of the agreement that constituted the hostage rather than the hostage itself. The treaty (fides) was the verbal expression of an agreement, while the hostage itself was the physical expression of the agreement. Walker points out that Dionysius of Halicarnassus describes how Lucius Tarquinius Superbus, Rome's last king, used violence against the hostage

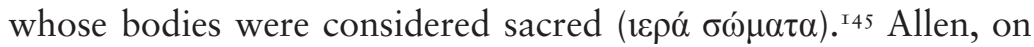
the other hand, indicates that the sacrosant status of the hostage is mentioned very few times, such as by Dionysius of Halicarnassus, so that it can not be considered as legio; no other of the hundreds of references to hostages suggests that they had a holy status. ${ }^{\text {I46 }}$

The hostage was the guarantee that the agreement would be held by the donors. ${ }^{\text {I47 }}$ There is nothing in these contexts that indicates that hostage was considered as 'holy' and enjoyed sanctioned protection in the same way as holy objects - and sacrosanct persons - and that they would therefore have been inviolable.

\section{Suspicion during negotiations}

Since the giving and taking of hostages were part of peace processes, misconceptions about them as persons could arise during the negotiations. Because the hostages were escorted to the areas of communication by the afore-mentioned cult specialists (in the Roman Empire) or by other men with the power to negotiate, they may have been viewed with the same suspicion as the negotiators.

The negotiators received a special protection. Certain rules of conduct appear to have existed for the messengers, who were inviolable, as guests, at least during negotiations between the Romans 
and Germanic peoples. In 374, the Suebian ruler Gabinius was invited by the Roman army commander Marcellinus under a special sacred, guest right. That kind of protection can be related to the international law - within the Roman legal system - jus gentium, a part of the civil law, jus civile. The protection concerned, according to Roman perception, messengers, but the Germanic side may have had a different opinion about its 'legality'. ${ }^{\text {I48 }}$

Suspicions could arise before peace meetings. This is a recurring theme in some Continental Germanic and Old Scandinavian myths. An example is found in one of the origin myths of the Saxons that explains the name 'Saxon'. At a peace meeting with the Thuringians, the Saxons are said to have hidden their seaxes, knives, under their robes, thereby the name Saxons. ${ }^{149}$ The myth of Týr and Fenrir described in Snorri's Edda portrays a similar context. ${ }^{150}$ These myths could primarily have served as example of what might happen if one did not act cautiously and correctly during negotiations, regardless of different 'sanctioned' protection at places of peace meetings.

Being hostage meant restrictions on personal freedom. But freedom was far greater for people with higher status than for a common prisoner or a slave. At the same time, this could change when the social capital of the hostage disappeared, something that could be seen in the case of Theoderic and Childebert, the sons of Gallo-Roman senators who were used as hostages in the early sixth century to secure a treaty between the sons of king Clovis I. When the peace was broken, the sons lost their value as hostages; they became slaves. ${ }^{\mathrm{I5}}$ The protection was no longer applicable because their fathers no longer held any influential positions. The example suggests that the treatment of a person who was hostage also was dependent on the safety of the hostage taker.

In Getica, Jordanes claims that the West Gothic ruler Theoderid (or Theodoric) had a daughter who married Huneric, son of King Gaiseric of the Vandals. In the beginning of the marriage they were content. Eventually Gaiseric suspected that Theoderid's daughter tried to poison him, so he cut off her nose and truncated her ears. Then he sent her back to her father in Gaul. According to Jordanes, the intention was to provoke Theoderid to claim revenge. ${ }^{152}$ In this case, apparently, marriage was originally a part 
of an alliance formation. Perhaps Gaiseric felt the marriage was an arrangement that did not suit him. If the tradition of marrying someone can be related to procedures of gift givings, we can see a vertical friendship here: the delivery of a bride becomes a forced subordination in this case by giving the bride. Gaiseric's suspicion became the triggering factor and, thus, the excuse for breaking the agreement in a position where he felt strong enough to challenge Theoderid.

A unique paragraph is found in the medieval Frisian law code Lex Frisionum (XX), which has a ban on executions of hostages. ${ }^{153}$ The law is written in Latin around the year 785 and is featured during peace talks between Franks and Frisians. Despite the fact that the law was made due to the Frankish initiative, it contains old Frisian law.

The above Continental Germanic examples may indicate that the cause for an abusive treatment of a high-ranking person who was given as a hostage depended on many things, including the political situation. Nevertheless, I have not found many cases or traces that a hostage as part of an agreement would have been treated poorly during Viking Age Scandinavia. The examples that I have already mentioned are the most extreme cases I could find in peace processes or bilateral agreements. To get further information about violence against hostage in Scandinavia, we must turn to medieval sources.

\section{Medieval contexts}

A few details in some medieval texts from Scandinavia - such as the Norweigian law Magnus lagabøters landslov - can provide us with information that the hostage has suffered violations and been subjected to violence. These details can be compared to Kosto, who points out late medieval continental examples in which the hostage was treated poorly, e.g. being starved or killed. However, according to Kosto, the hostage was generally treated well during the Middle Ages, although there were exceptions. As pointed out earlier, Kosto believes that the treatment of hostages was determined by how they were socially valued and how they were expected to be treated: ${ }^{154}$ 
[...] particularly for earlier periods, most of the hostages we know about were either noble or wealthy enough to merit (or negotiate) good treatment. Furthermore, many hostages of lower status were handed over pursuant to agreements negotiated by powerful people and thus the condition of their confinement reflected their patrons' influence. Where hostages are treated well, in other words, it is as likely to be because of who they were as because of their status as hostages. ${ }^{155}$

Similar structures with examples of social differences in the treatment of hostages can be found in the sagas (medieval cases) and in the medieval Scandinavian laws and diplomas.

It was a duty to return a hostage unscathed, as pointed out by the Scandinavianist Dag Gundersen; should it, on the other hand, be forfeited, the hostage could be blinded. ${ }^{156}$ One can assume that the hostage was treated well if someone did not violate the agreement, which is stated in the Magnus lagabøters landslov. If the King mistrusted the householders to not give him support in a conflict they were expected to give hostages to prove their loyalty. The king was also expected to return the hostage 'not mutilated'. ${ }^{157}$ Here, it is explicitly mentioned that it was mutilation that awaited the hostage and not death, which we will return to. It is also suggested in the law, which was an instrument of power, that the hostage was not to be used in direct negotiations. The king would use this tool if the householders refused to perform military service in wartime. The lives of a householder might be less valuable in this context. This is the question of the conditional hostage, i.e. the hostage was used as security because the houeseholders in such cases violated an agreement that existed between them and the royal power.

Another of Gundersen's sources is Orkneyinga páttr, a part of Flateyjarbók's version of Olafs saga hins helga (Saga of St. Olaf). Thorfinn (Porfinnr), son of the Earl of the Orkney Islands and Caithness, Harald Maddadsson (ON Haraldr Maddaðarson [d. I 206]), was held hostage by the Scottish king William the Lion (ON Vilhjálmr). William had Thorfinn blinded. In the Orkneyinga saga it is briefly mentioned that William previously had Thorfinn whipped. ${ }^{15} 8$

There are several cases of blindings in the Orkneyinga saga. ${ }^{\mathrm{I} 59}$ At one occasion Earl Harald arrives to the castle Scrabster (ON 
Skarabólstaðr) in Caithness. He then blinds the bishop and cut off his tongue. The bishop was then aided by a woman who brought him to the grave of Saint Triduana (ON Trollhoena), where he got his vision and speech back. The case is obviously a miracle story, and then one can interpret the blinding as a topos that is linked to a New Testament model. ${ }^{160}$ There are even other cases of blinding in Old Western Norse literature. In Heimkringla's version of Saint Olaf's saga, Olaf Haraldsson surrounds - as was his custom - a building with oposing 'kings'. After capturing them, he had King Hrœrekr blinded because he did not trust him and cut off the tongue of King Gudrøðr. The others had to swear to leave Norway and never return. ${ }^{\mathrm{I}}{ }_{\mathrm{I}}$

Based on only the sagas, it is not possible to conclude that hostages could be blinded in case of breaches of the agreements that were secured with hostages. However, in medieval legislation, it was implicit that violence was actually used against people who were held hostage, at least in the Norwegian medieval realm. In the above stories, the distinction between being a captive and a hostage also emerges: in the former case it is a person that was handed over through the mercy of their capturer. The well-being of the hostage depended on the behaviour of their own side and thus responded to a completely different political situation. Still, there are cases where medieval legislation can provide information about both the protection of hostages and the violence directed against them, which in both cases can be related to negotiations.

In the medieval provincial laws, it can be difficult to distinguish between a 'personal hostage' (Germ. Borgensgeisel) and a 'public hostage'. The lawyer and political scientist Poul Meyer believed that the former category is the oldest in the Danish provincial laws. ${ }^{162}$ However, in the Swedish provincial laws there is a distinction between the public hostage and the personal hostage. In the Upplandslagen, the provincial law of Uppland and the Östgötalagen, the procincial law of Östergötland, there is a difference in how to value the hostage. In the Östgötalagen, a special crime is stipulated in the section about manslaughter (Sw. Drapsbalken): if a criminal is removed from the captor, he has violated the law of hostage (gislingabrut). ${ }^{163}$ The same crime is also stipulated in the section about crime that is accidentally 
committed (OSw Vådamailsbalken) and the section about lawsuits (Sw. Rättegångsbalken). ${ }^{164} \mathrm{He}$ who had the main responsibility should forfeit 40 marks. These cases concerned individuals and groups on a private, personal, level. ${ }^{165}$

In the paragraph on personal peace (Sw. Manhelgdsbalken) in the Upplandslagen it is stipulated that if a person who is hostage is beaten or killed, he (or his kin) shall be compencated with the much higher amount of I 40 marks:

$\mathrm{Nu}$ kan kunnugær gislæ hawæ. wærper han (wæghin ok slaghin (gildær mæp hundræpe markum ok firuætighi. ${ }^{166}$

$\mathbb{S} 8$. Now the King may have a hostage; if he is beaten and killed, he shall be fined for with a hundred marks and forty. ${ }^{167}$

(My transl.)

This protection applies to the traditions around the Eriksgata, which are listed in several provinical laws, including the Upplandslagen (confirmed I296). ${ }^{\text {I68 }}$ The fine in the paragraph on 'personal peace' is equated with other types of crimes that also render 140 marks in fines. These crimes concerned different types of violations within locations where people received some protection: ${ }^{169}$

$\mathbb{S}$ I. In their homes or within the four boundary markers ( $\mathrm{Sw}$. ramärken) of the common lands of the village.

$\mathbb{}$ 2. At a church or a graveyard within the distance of sixty fathoms.

$\mathbb{S}$. At a thing place that is 'ancient' and 'lawful'.

$\mathbb{S}$ 4. A father who is killed in the home of a married son, or at his own farm, within the distance of a spearhead and an axe-haft from the farm.

$\mathbb{5}$. In the forge or within the distance of a hammerthrow or a pair of nippers from the forge.

$\mathbb{S} 6$. If a man has tried to deceive concerning a homicide outside the communities. ${ }^{170}$

$\mathbb{5}$ 7. A sick person who has been left on an island.

\9. The king's tax collectors and servants are beaten and killed when they are out traveling.

$\mathbb{S}$ Io. If a lawman is beaten and killed when he when he pronounces judgement on the law of the country. 
It is possible that some of these paragraphs go back to older provisions such as the measure of how far a hammer can be thrown. According to the lawyer and legal historian Åke Holmbäck and the philologist Elias Wessén, the distance of sixty fathoms has replaced the (older?) measures of hammer and spear throws. ${ }^{17 \mathrm{I}}$

Paragraph three on the protection at a thing place that is 'ancient' and 'right' is even more important, in my view. Holmbäck and Wessén do not comment on this characteristic, but the reference to the age of thing places suggests that if they were used in elder days, they built on an authority that was anchored in the local community. The right to protection may very well go back to older traditions. It is therefore interesting that even the lawspeaker, whose traditional role was to memorise and recite laws, is also mentioned in the paragraph on personal peace (or safety).

Because the protection with personal peace involves both towns and villages as well as the king's hostage during the ritual journey of the Eriksgata, one can compare the latter example with the mobile cult places. The possibility that hostages traveling to thing places had a specific protection could also be the case during peace negotiations. However, it cannot be argued that those persons who had this kind of protection were untouchable in the sense that they had a holy or sanctified protection.

Violence took place in the places listed in the paragraphs, despite the protection, which, in its medieval context, was mainly by the law except for the protection at the churches that was constituted by the Canonic law. One can compare this with Elbern's assertion of hostages in the Roman Empire as 'sacrosanct'. In fact, the paragraph on personal peace suggests that assaults on hostages actually occured. However, it is possible to speak of a 'protection' with its roots in earlier times.

Of the above-mentioned texts there are two main situations where the hostage is used that correspond to the basic premise for bilateral and unilateral hostages:

(A) At an occasion with a more or less voluntarily given or taken hostage on an uneven basis. There was no room for compromises and the behaviour of the side of the hostage largely governed the treatment. This feature had a vertical 
structure and can be said to have been unilateral as in the case of the law code of Magnus IV of Norway, Magnus lagabøters landslov.

(B) Situations in which the hostage had (personal) protection during peace negotiations and the protection was regulated by legal rules for different areas of communications. The protection also concerned the 'hostage' on an even more personal level (see the case of Prince Valdemar, below). In these situations, a horizontal structure is found, which was both bilateral and unilateral. The behaviour of the hostage's own side was crucial for his or her wellbeing, but to a lesser extent. The social value of the hostage was also of significance.

There is additional information to add to the discussion on the personal protection. This can be done through a review of places and terms for protection in peace talks in Viking and medieval contexts. Before that, the hostage case of Prince Valdemar of Denmark is described.

\section{Prince Valdemar as hostage}

In a Danish medieval diploma from the $\mathrm{I} 3$ th century, it is stated that the hostage should reside in a particular place and not leave it without the consent of the hostage agency. The background was that Count Henry I of Schwerin managed to capture Valdemar II 'the Victorious' (Da. sejr) of Denmark and his son Valdemar 'the Young' on the island of Lyø, south of Funen in May I223. Henry was actually a vassal of the Danish king. However, he negotiated with the Holy Roman emperor Frederick II - who acted as a third party - so that Valdemar and his son were to be extradited to the emperor. In the agreement, Henry demanded that all the lands conqured by Valdemar in the province of Holstein would be handed over to him and Valdemar was obliged to pay 52,000 pieces of silver to the Count and his friends. ${ }^{172}$

The agreement also stipulated that 'the young king of Denmark' should be kept at the castle of Harzburg (in the present Lower Saxony) under the supervision of 'captains' (Da. høvedsmand) 
and ministerials in the emperor's service. ${ }^{173}$ 'The Old King of Denmark' would remain with Henry of Schwerin:

until Most Reverend Archbishop of Cologne and the above-mentioned Count of Schwerin [Henry] wishes to inform, whether they can engage the kings of Denmark to acquire the mercy of the emperor and of the king, either by payment or by repatriating the lands they have deprived emperor and kingdom, or whatsoever any other means. ${ }^{174}$

(My free translation)

Although the word 'hostage' is not mentioned in this paragraph of the diploma, it is implicit. The hostage guaranteed that the agreement should enter into force. The Danes rejected the requirements, and without Valdemar they suffered a defeat in January I 225. Not until Easter I 226 were Valdemar and his son released upon the payment of 18 , 000 pieces of silver, and Valdemar's three other sons were admitted as hostage. ${ }^{175}$

This later arrangement could be compared to what Kosto refer to as 'custodial hostage'. The sons stood as a guarantee for a third party while the remaining sum would be collected. The diploma contains no more details about how Valdermar's son, the future king Valdemar, should be treated. It must not be doubted that it was anything but an 'honorable' custody. It was thus the captivity and detention that was the purpose of hostageship and not the external violence. Such a thing occured elsewhere in Scandinavia. Prince Valdemar was thus treated due to his position.

\section{Places and terminology for protection during negotations}

In places with protection during peace negotiations, it was possible to safeguard the hostage during the negotiations and the delivery of the hostage. These places were what I refer to as ares of communication. In order to understand how these places were designed, it is necessary to investigate the terminology that was used. I therefore discuss the words describing peace and a state of restrictions on violence: friðr and grið. 


\section{Friðr}

For the temporary hostage used during peace talks, special safeguards might have been applied. The hostage probably had the same protection as the person for whom it was pledged as security. This protection was mainly derived from the negotiations in the areas of confrontation between the Anglo-Saxons and the Danes or other Scandinavians, as described in various chronicles. The hostage form primarily used in direct negotiations was the 'true hostages' (see Part I), but there may also have been other forms of hostages. Thus, protection and regulations for hostages can be mainly related to the places where negotiations took place. But it is also important to clarify the difference between the Old Western Norse concepts of friðr and grið.

In Old English there are terms for protection during negotiations at certain places. The term frēoðo-burh (alt. frēo-burh) that can be translated as 'town, stronghold [...] the sacred peace attaching to the king's dwelling in the laws'. ${ }^{176}$ The modifier in this designation can be derived from the Old English frēod, 'peace' or 'friendship'. There is an analogy in the Old English frip (alt. frið), the verb frēogan, 'to liberate' or 'to love', and the adjective frēo, 'freedom', 'noble', or 'happy'. ${ }^{177}$

The Germanist Heinrich Tiefenbach states in his characteristic of the Germanic and Scandinavian 'peace' (ger. Friede) that:

On the whole, the finding can be interpreted that apart from the function of designating ties within the closest social group ('love, friendship'), the meaning components 'protection, security' were dominant in the Germ[anic] "fripu. The features 'state without war/conflict', which can be: detected early on, have probably above all received its coining power for the hist[ory] of the meaning of the word under the influence of Christian ideas of $\mathrm{p}$ [eace].

According to this definition, the word could have initially been used within a closed community, as in the environments of the halls. The definition can be compared to the historian Johannes Steenstrup's view that peace ( $f r i ð r$ ) eventually came to mean something that was more 'objective' (than grið) and existing throughout the society. ${ }^{178}$ 
Kershaw believes that Old English frip, with cognates in both Scandinavian and in West Germanic languages, may originate from the perceptions of order in the relationships of family and friendship. ${ }^{179}$ The Old English word frip seems to characterize the order in different types of places such as the king's hall, a saint's crypt, the sanctuary of the church and the monastery. Sometimes this arrangement could comprise an entire area. It was primarily places with the significance of an ideal order. This applies primarily to the order prevailing in Anglo-Scandinavian areas of communication as described with Old English terminology. As a comparison, it is relevant to see if a similar terminology, which indicates the level of protection during negotiations, can be found in Scandinavian areas of confrontation, using information in skaldic and Eddic poems.

To understand places with protection, it is essential to highlight the contextual differences between the Old Western Norse words friðr and grið. As far as peace is concerned, it is evident that in late skaldic poems ( $3_{3}$ th-I 4 th centuries), such as the Máriuvísur, it appears in Christian and biblical contexts with the meaning of 'heavenly peace'. The transcripts made by the earliest skalds and directly related to war are more relevant. Among other things, Sigvat wrote the poem in his erfidrápa (I I th century) on the death of Olaf Haraldsson (c. I040) 'that there was an end to peace' (friðbann var par monnum) when archers fired their arrows at Stiklestad (IO3O). ${ }^{180}$ The word Friðbann could be interpreted as a kind of standstill before the battle. However, the head -bann can be related to the verb banna, 'to forbid', 'to condemn', or 'to curse'. The word friðbann is a kenning that suggests that peace is broken rather than a direct connection with the war.

Several places with names that include the modifier friðr-are mentioned in Old Norse sources even if the actual meaning is not always evident. Friðland appears as an idyllic land in the skaldic poetry. In the skaldic poem Háttatal (stanza 43), Fróða friðbygg is mentioned, but it is a metaphorical description of the 'peaceful order' under the mythical ruler Fródi. In addition, a stanza in the skaldic poem Velleka (Ioth century) by Einar Helgason (ON Einarr Helgason) refers to the fact that there was no warrior on earth who arranged such peace (slikr friðr) as Fróði. ${ }^{181}$ 
There is plenty of proof for the word friðr in pre-Christian contexts, but neither in the Eddic poetry nor in the skaldic poetry is it directly linked to negotiations. The combination of gefa and friðr denotes metaphorical rewritings to break the peace of another person, an enemy or a victim: gefr hánum engi frið (Havamál), 'gave him no peace', or at gicefim gridbitum frid litinn, 'to give the breakers of the truce little peace'. ${ }^{182}$

There is one exception where friðr is recorded as a single word, in the phrase friðar at biðja ('to ask for peace') in the eddic poem Hárbarðsljóð and in the skaldic poem Haustlong (stanza 8) varð Pors [...] friðar biðja ('Thor's friend [Loki] [...] asked for peace'). ${ }^{183}$ The poetic expressions appear ambigious in these cases. It could be interpreted as an appeal for a desired sanctified protection rather than a peace treaty, because it is not evident that the myths alluded to are between groups such as the gods and the jötnar or between the indivdiuals Loki and Thor. Otherwise, the word appears in the metaphorical rewritings for the breaking of peace, or the 'truce', for example, frið glepsk, 'the hurting peace'. ${ }^{184}$

There are also places for protection with friðr-, 'peace', in the modifier as in the Old English friðgearð och friðsplott, 'peacekeeping' and 'peace plot'. According to Tiefenbach, these places would be 'heathen', but at the same time have to do with the 'heavenly dwelling' (Germ. Gefilde) and Christ. ${ }^{185}$ One can compare with the suggestion by Elmevik: Friggeråker ( $\mathrm{OSw}$ Frig(g)iceraker) in the district of Gudhem in Västergötland may be derived from a possible Old Western Gohtic *Friðgcerð(ar)aker. ${ }^{186}$

According to the language researcher, the linguist Johan Fritzner the word friðgerð (f.) meant 'peacemaking', 'settlement of peace'. The word is found in the title of the Friðgerðarsaga, a story about peace makings in Iceland. In Stjorn: Gammelnorsk Bibelhistorie, published in I 862, the word friðgerðarlogmál appears, which Fritzner interpreted as 'truce' or 'settlement'. ${ }^{187}$ Evidently, these sources are vague and belong to medieval contexts. Perhaps friðgerð, in its pre-medieval contexts, refered to the 'peace' at the $v i$-place, which was surrounded by a vebond as proposed by Elmevik.

No evidence in the skaldic poetry indicates that there was a place with the modifier friðr- where negotiations were conducted 
outdoors. However, there is an Old Western Norse adverb friðssamligr, 'peaceable', and an adjective that may suggest that such a word existed before the I 2 th century. Both of these words are found in the Flateyjarbók (II) from the I4th century, and again it is a matter of contexts that indicate a peaceful state. ${ }^{88}$

As a condition, peace may have been important for the 'peace'like state that existed in the hall, for example during a banquet. The personal name Hallfred may possibly suggest that there was a peace in the hall, e.g. in the Runic Swedish female names Hallfriðr (Hall- + -(f)reðr/-(f)røðr) and Hallfriðr (Hall-, 'hall', + -frīðr, 'peace'). ${ }^{189}$

In the Eyrbyggia saga, in the episode about Thorolf Örnólfsson (OI Pórólfr Qrnólfsson Mostrarskegg), the word friðstaðr is used by the writer. The farm Hofsstaðir that Thorolf built on the foreland of Pórsnes by the river Pórsá in the fjord Breiðafjörður was inside declared 'to be in peace' (friðstaðr). ${ }^{190}$ In this episode, there are some interresting names and descriptions of Thorolf's land ownership around Pórsnes. For example, the township at Pórsnes was a 'holy place' (helgistaðr). ${ }^{\text {19I }}$ The sanctification of these places may reflect a will where the hallowing of the land coincided with the ambition to legitimize the land ownership, not only legally but also by religious tradition. The word friðstaðr does not appear in any version of the Landnámabók's version of the story about Thorolf, so it is hard to know if the word, in this case, is a part of an authentic tradition or not.

As an example of a possible temporary protection before negotiations, the truce-shield, frið-skoldr, could be mentioned. In connection with the use of the truce-shield, there is an example in which one side wanted to ritually demonstrate their peaceful intentions during peace processes where hostages were used. At the same time, they violated the terms of truce, and the area of communication was therefore deliberately turned into a confrontational area. The Annals of Fulda (Annales Fuldenses) describe how a Frankish army under Charles the Fat (Fr. Charles Le Gros) laid siege to a group of Scandinavians at a fortress called Asselt in Friesland in 882. According to the annals the Scandinavian chief, Godafrid, called $d u x$, bribed the 'false' bishop Liutward and his associate count Wigbert to convince the Emperor not to attack 
the Northmen. ${ }^{192}$ Liutward introduced Godafrid to Charles. The Emperor was kind to Godafrid and made peace with him, whereupon the hostage was exchanged. The Northmen took it as a good sign and raised the truce shield to show their good intentions. When some Franks entered the fortification to trade, the Northmen immediately lowered the shield and closed the gates. All Franks inside the fortress were killed or captured for later use in ransom negotiations. The Emperor chose to ignore the incident. Later Godafrid accepted baptism and received some lands in Kennemerland as a gift. Other Northmen returned to their homelands with robbed goods and 200 prisoners, and they waited for the next occasion for plundering. ${ }^{193}$ The chronicle is tendentious as it is angled from the perspective of the Franks. The case exemplifies, though, how people were not inviolable during negotiations even though there was formally a 'truce'. The truce shield marked a place where it was supposed to be a temporary peace.

\section{Grið}

The word grið, as mentioned previously, seems to have a clearer connection with negotiations in the sense that the word indicated that the warriors had temporary protection from further acts of violence. In various medieval legal conflicts, there is a sanctioned protection for individuals, either (a) a homeless woman (griðkona) or a man (griðmaðr) who is accepted into another's home, or (b) a temporary protection in a place before a trial. ${ }^{194}$

The concept of grið occurs in the skaldic language in different contexts about truces (Figure IV.3). Of particular interest are the combination verb + grið as in nefna grið, 'announce (to) peace'. In Pórgeirsdrápa, there is griða aesta, 'to pray for truce (or safe conduct)'. Arnórr Pórðarson jarlaskáld's memory drapa dedicated to Harald Hardrada (Erfidrápa um Harald konung harðráða) indicates that the Norwegians did not want peace (vilja grið) but preferred to fall with the king. ${ }^{195}$ In a skaldic stanza in Ragnars saga, Ragnar's wife, Kráka, asks if he wishes to keep the peace (ef vilttu griðum pyrma). ${ }^{196}$ The verb expresses actions such as 'to will', 'to ask', 'to desire', 'to hold', or 'to give' in combinations with grid, which in the more unambiguous sense meant that a truce, 


\begin{tabular}{|c|c|c|c|}
\hline Word & Meaning & In contexts & Sources \\
\hline \multirow[t]{11}{*}{ grið (pl.) } & $\begin{array}{l}\text { 'safe conduct, } \\
\text { truce, security' }\end{array}$ & gefa grið & $\begin{array}{l}\text { Bjarni Kolbeinsson } \\
\text { Jómsvíkinga drápa } 44 \\
\text { ( } 3 \text { th century) }\end{array}$ \\
\hline & $\begin{array}{l}\text { 'truce; life' (the } \\
\text { time of safe } \\
\text { conduct a killer } \\
\text { has before trial) }\end{array}$ & $\begin{array}{l}\text { selja einum } \\
\text { grið }\end{array}$ & $\begin{array}{l}\text { Sólarliód } 2 \text { I 'The } \\
\text { song of the son' (I } 3 \text { th } \\
\text { century) }\end{array}$ \\
\hline & & $\begin{array}{l}\text { nefna }[\ldots] \\
\text { (?) grið }\end{array}$ & $\begin{array}{l}\text { Sigvat skald Flokkr } \\
\text { about Erlingr } \\
\text { Skjalgsson } 4 \text { (I026) }\end{array}$ \\
\hline & & cesta griða & $\begin{array}{l}\text { Pórmóð Bersason } \\
\text { Kólbrunarskald } \\
\text { Pórgeirsdrápa I I } \\
\text { (Iо30) }\end{array}$ \\
\hline & & vilia grið & $\begin{array}{l}\text { Arnórr Pórðarson } \\
\text { jarlaskáld Erfidrapa of } \\
\text { king Haraldr harðráði } \\
\text { I } 5 \text { (I067) }\end{array}$ \\
\hline & & $\begin{array}{l}\text { halda } \\
\text { griðum }\end{array}$ & $\begin{array}{l}\text { Gizurr Porvaldsson } \\
\text { Drapa of Hakon the } \\
\text { Old ( } 13 \text { th century) }\end{array}$ \\
\hline & & $\begin{array}{l}\text { pyrma } \\
\text { griðum }\end{array}$ & $\begin{array}{l}\text { Stanza in Ragnars saga } \\
\text { loðbrókar } 3 \text { ( } 3_{3} \text { th } \\
\text { century) }\end{array}$ \\
\hline & & $\begin{array}{l}\text { koma } \\
\text { griðum } \\
\text { við[sic.] }\end{array}$ & $\begin{array}{l}\text { Oddr breiðfirðingr } \\
\text { Illugardrapa } 2 \text { ( ( } ૦ \circ \circ)\end{array}$ \\
\hline & & $\begin{array}{l}\text { iðrask } \\
\text { griða }\end{array}$ & $\begin{array}{l}\text { Grettir Ásmundarsson } \\
\text { Lausavísur } 9 \text { (IO28) }\end{array}$ \\
\hline & & $\begin{array}{l}\text { roena } \\
\text { griðum }\end{array}$ & $\begin{array}{l}\text { Bjarni Kolbeinsson } \\
\text { Jómsvíkingadrápa I9 } \\
\text { (I3th century) }\end{array}$ \\
\hline & & $\begin{array}{l}\text { véla i } \\
\text { griðum }\end{array}$ & $\begin{array}{l}\text { Stanza in Hálfssaga } \\
\text { VI } 4\end{array}$ \\
\hline
\end{tabular}

Figure IV.3. Derivations and compositions with grið- in Skaldic and Eddic poetry. Source: Lexicon Poeticum ([ed.] Finnur Jónsson): 203. 


\begin{tabular}{|c|c|c|c|}
\hline Word & Meaning & In contexts & Sources \\
\hline & $\begin{array}{l}\text { 'attempting to } \\
\text { break the truce' }\end{array}$ & $\begin{array}{l}\text { byggia á } \\
\text { griðum }\end{array}$ & $\begin{array}{l}\text { Atlamál } 33 \text { (Eddic } \\
\text { poem) }\end{array}$ \\
\hline & & grið létusk & $\begin{array}{l}\text { Hallr Pórarinsson } \\
\text { Háttalykill I } 4 \text { b ( I I 4os) }\end{array}$ \\
\hline & & $\begin{array}{l}\text { grið } \\
\text { grennask }\end{array}$ & Ingjaldr \\
\hline & & & $\begin{array}{l}\text { Geirmundarson } \\
\text { Atloguflokkr } 5 \text { (I 244) }\end{array}$ \\
\hline & $\begin{array}{l}\text { 'to give gold } \\
\text { without conduct' }\end{array}$ & $\begin{array}{l}\text { láta slitna } \\
\text { grið gulli }\end{array}$ & $\begin{array}{l}\text { Einar Skúlason } \\
\text { Øxarflokkr } 6 \text { (?) }\end{array}$ \\
\hline & $\begin{array}{l}\text { 'safe conduct } \\
\text { from the } \\
\text { einherjar' }\end{array}$ & $\begin{array}{l}\text { Einherja } \\
\text { grið }\end{array}$ & $\begin{array}{l}\text { Eyvindr Finnsson } \\
\text { Skáldaspillir } \\
\text { Hákonarmál I6 (96I) }\end{array}$ \\
\hline & $\begin{array}{l}\text { 'someone who } \\
\text { bites, the truce, } \\
\text { trucebreaker' }\end{array}$ & griðbitr & $\begin{array}{l}\text { Hásteinn } \\
\text { Hrómundarson halta } \\
\text { Lausavísur4 }(955)\end{array}$ \\
\hline & & griðbitr & $\begin{array}{l}\text { Gunnlaugr Leifsson } \\
\text { Merlínusspá I I } 8\end{array}$ \\
\hline $\begin{array}{l}\text { griðfastr } \\
\text { (adj.) }\end{array}$ & $\begin{array}{l}\text { 'holders of safe } \\
\text { conduct' }\end{array}$ & $\begin{array}{l}\text { griðfastir } \\
\text { friðmenn }\end{array}$ & $\begin{array}{l}\text { Pórarin lovtunga } \\
\text { Tøgdrapa } 5\end{array}$ \\
\hline griði & $\begin{array}{l}\text { 'to give safe } \\
\text { conduct' }\end{array}$ & $\begin{array}{l}\text { Grimr } \\
\text { griði minn }\end{array}$ & $\begin{array}{l}\text { Volundarkviða Io } \\
\text { (eddic poem) }\end{array}$ \\
\hline griðkona & $\begin{array}{l}\text { 'maid, female } \\
\text { servant' }\end{array}$ & & $\begin{array}{l}\text { (Pórðr Kolbeinsson) } \\
\text { Lausavísur I }\end{array}$ \\
\hline $\begin{array}{l}\text { griðmildr } \\
\text { (adj.) }\end{array}$ & $\begin{array}{l}\text { 'who likes to give } \\
\text { (enemies) truce } \\
\text { and safe conduct, } \\
\text { (about Hakon the } \\
\text { Old)' }\end{array}$ & & $\begin{array}{l}\text { Sturla Pórðarson } \\
\text { Hrafnsmál } 6 \text { (1263) }\end{array}$ \\
\hline griðningr & $\begin{array}{l}\text { 'someone who } \\
\text { breaks their } \\
\text { truce promise, } \\
\text { trucebreaker' }\end{array}$ & & $\begin{array}{l}\text { Árni Jónsson } \\
\text { Guðmundardrápa } 42 \\
\text { (I4th century) }\end{array}$ \\
\hline
\end{tabular}

Figure IV.3. Continued 
including negotations, were to be conducted (Figure V.3). One can thus give and receive grið in the event of a war. ${ }^{197}$ Other skaldic stanzas, as in griðningr, indicate a possible breaking of the truce, the peace, or the safe conduct which suggests that a special 'peace' during the truce could not be broken.

In the case of grið, we can see place names with the combination of grið + a word for place. These places with grið- in the modifier may have been places of negotiations which involved the use of hostage as a security. This is supported by the combination (OSw) gilzla and grutha in Swedish medieval laws (see further below).

At least one Old English source refers to a building called griphus where negotiations were conducted. It could be compared to an English place name, Gribthorpe, Yorkshire, (OE Gripp's thorp [I23I]), which can be derived from an Old Danish grip or an Old Western Norse grið. ${ }^{198}$ There are no known Old Western Norse or Old Eastern Norse sources mentioning a special building for truces and negotations. However, in the Old Western Norse sources there are names such as griðasala and griðastaðr. The latter word can be seen in the prose introduction of the eddic poem Lokasénna: Par var griðastaðr mikill, 'it was a great place of peace'. ${ }^{199}$

According to Steenstrup, grið was used as the designation of 'peace' or 'protection' in a single place, which, according to Steenstrup, could be the cult building of a hof or a church; it was the place that was protective and not what was protected; it was an asylum right rather than the sanctity of churches. ${ }^{200}$

There is also a specific term for the ritual act through which a place was determined to serve for negotiation: griðasetning. Alternatively, it is only about the Old Norse satt or sett seen There is also a specific term for the ritual act through which a placewas determined to serve for negotiation: griðasetning, 'treaty' or 'fraternity'. The term griðasetning should more accurately reflect how peace should be understood as a place of negotiation and can be related to contexts as in Eyrbyggia saga: at grið varu sett með monnum, par til att hverr komi til sins heima, 'so that a truce was issued between the men, which lasted until every man came to his home'. ${ }^{20 r}$

Obviously, there was a sanctioned protection - which was perceived as strong - in connection with grið, as suggested by the 
use of kenningar for 'truce-breaker', like griðbitr, and griðniðingr, such epipithet was not desireable. As a negotiator or participant during negotiations, one had a sanctioned protection through the grið. The sanctioned protection can be found in various stories. In the skaldic poem Hákonarmál, King Hakon will have safe conduct from the ever-violent einherjar as a mark of honor when he arrives at Valhall. ${ }^{202}$

In the same category is the story of the battle of the Alptafjord in Eyrbyggia saga, when Snorri Goði and Steinpórr meet to confirm the truce (grið). Steinpór asks Snorri to hold out a hand. When Snorri does, Steinpór strikes with the sword against Snorri's hand; the blade hits the stallabringr, the ceremonial ring, which breaks but the hand remains unscathed. ${ }^{203}$ The episode can of course be interpreted in several different ways but may possibly be perceived as an intervention from some kind of being who caused the ring to come between the sword and the hand, thereby protecting the gríd.

In Grágás, a medieval, Icelandic law, grið figures prominently in combination with friðr in a formal manner, but it clearly shows that the two words had different meanings. ${ }^{204}$ In paragraph I 22 the law says: Pað er uphaf að pessu máli að eg set grið ok frið á milli peirra N. og N, 'As introduction to this case I proclaim truce and peace between N.N. and N.N.' ${ }^{205}$

The same word pairs are found in Heimskringla's version of the Saga of St. Olaf, in the aforementioned peace meeting between the Norweigians and the Swedes at Uppsala in ror 8. At the thing the lawspeaker Torgny responded to the king of the Swedes, Olof Skötkonung, and his expansive plans in Norway. There is a dialogue between the king and Rögnvald Earl from Västergötland, during which the king accuses the earl of having made a truce and peace ( hafði gort grið ok frið) with King Olaf Haraldsson. ${ }^{206}$

In these contexts, friðr is the peace you are striving for, while grið stands for the temporal truce and is limited in time and space. These concepts appear as an alliterative word pair that reinforces the impression of continuity from older traditions. There is also other medieval Scandinavian legislation with alliterative word pairs with words for peace and hostage. 


\section{gilzla and grutha in Swedish medieval laws}

In the Swedish medieval laws, there is a text formula that can be related to both hostage and grið. In the laws describing the Eriksgata - the king's ceremonial journey to different provinces before the coronation - there is the formal expression mop grupum oc gislum, 'with safe conduct and hostages'. ${ }^{207}$ This expression meant that the king was promised safety for his life, with hostages as a security and safe conduct, as he traveled to the thing during his Eriksgata. This will be addressd in Part VI.

Alliterations are common in Old Norse texts, which for example can be seen in a section in the Icelandic law code Grágás, known as the Griðamál; there are alliterative formulas such as grið og fullan frið, fégrið and griðníðingur er griðum. ${ }^{208}$ However, one law text has been perceived as standing apart of the Eriksgata traditions and can be derived from an independent oral tradition. In the Smålandslagen ('the law of the province of Småland', alt. Tiohärads lag) the Church section says:

Gwz frither oc sancte marie. vari meth us. hiit komande. oc haethan farande. The seen alle skylde till gilzla oc grutha. ey æru bilthuga eller banzatte. alle the som boa innæn mioahalt. oc myrtleiks. oc. maellin brutabek oc biureiks. ${ }^{209}$

God's peace, and holy Mary's, is with us, who have come here and shall depart. They are all obliged to give hostage and safe conduct, [those] who are not outlawed or bannished, all those who live within Mjöhult and Mörtlek and between Bråtabäck and Björkö. ${ }^{210}$

(My translation)

The Church section is preserved in two manuscripts from the I 4 th century: the A manuscript from the Skokloster collection at the Swedish National Archives (cf. Figure IV.4) and Schlyter's B manuscript (cf. Figure IV.5), today in the Arnamagnæan Manuscript Collection in Copenhagen.

One phrase in particular in the Church section has been discussed: The seen skylde till gilzla oc grutha. A question historians and legal historians have asked has been in what relationship this text passage stands vis-à-vis other provincial laws. The legal historian Carl Johan Schlyter theorized that the passage consists of 


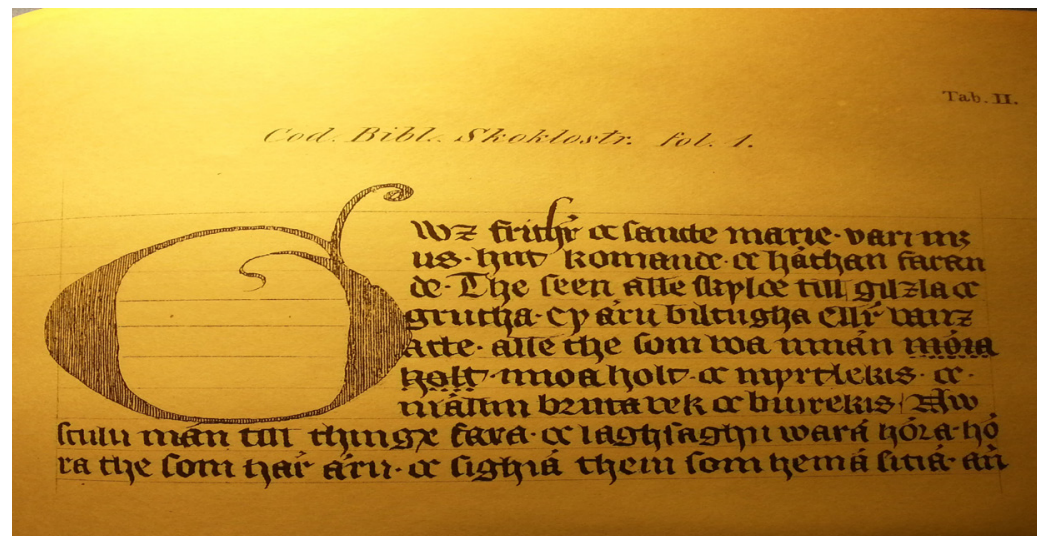

Figure IV.4. A manuscript of the introduction to the Church section in the Smailandslagen, from the Skokloster Castle collection (today in the National Archives of Sweden, Stockholm). Source: Samling af Sweriges gamla lagar, ed. Carl Johan Schlyter; the word gilzla is marked. Photo: Stefan Olsson.

material from an elder King's section that was transmitted from some of the manuscripts on the Eriksgata because these texts (Upplandslagen, Magnus Erikssons landslag) mention that the king had the right to receive hostages and safe conduct before he entered the provinces with his retinue.

He therefore concluded that the Church section was not of old age because the Tiohärad lagsaga (an ancient legal district based on the härads, 'hundreds') was not formed until I 296. Only then can it be confirmed by the Upplandslagen that the people of the Tiohärad lagsaga received the king during the Eriksgata. ${ }^{2 I}$

Holmbäck and Wessén claimed in their commentaries on the law that this phrase was a part of an earlier King's section (Sw. kungabalk) that was added through a transfer from other law traditions and it was older than the fixation in writing of the law of Uppland (Upplandslagen). ${ }^{22}$ They nevertheless considered the province of Småland to be inclueded by the journey of the Eriksgata and that the concepts of gilzla and grutha belonged to this tradition. At the same time - according to both the Westrogothic laws - the jurisdictional district of Småland (Sw. Tiohärads lagsaga) was not included in the Eriksgata. ${ }^{213}$ Those who were to be handed out by the Eastern Geats (Sw. östgötar) as hostages only 


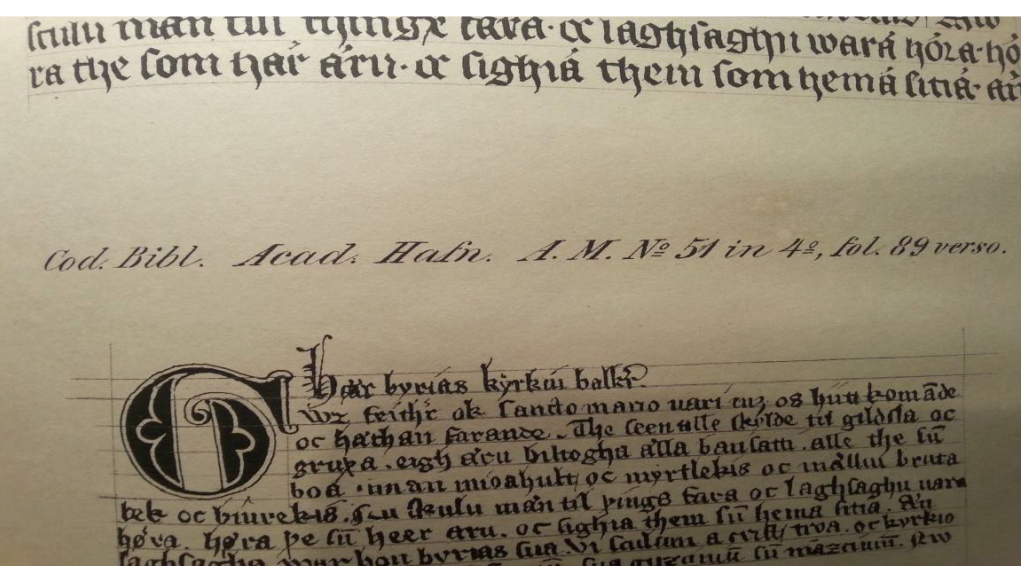

Figure IV.5. B manuscript of the Church section in the Smålandslagen in the Arnamagnæan Manuscript Collection in Reykjavík. Source: Samling af Sweriges gamla lagar, ed. Carl Johan Schlyter; the word gildsla is marked. Photo: Stefan Olsson.

followed the king to Junabäck (at present Jönköping) to meet the Westrogoths (Sw. västgötar). On the other hand, in the King's section of the law of Uppland, this had changed: the representatives of Småland would meet the king with the hostages at Holaved in Östergötland and follow him to the river Junebäcken. ${ }^{214}$

The historian Folke Dovring dated the Church section to an earlier time than the I 3 th century. He assumed that the text could be analysed based on its age-old character. Dovring pointed out that the phrase gilzla oc grutha was structured as alliterative word pairs, as was the case with several other phrases in the Church section. ${ }^{25}$ The wordpair gilzla and grutha did not refer to any outlaws because they stood outside the society and did not have reason to attend the celebration of the king. Instead, the word pair refers to the conditions within the jurisdictional district and designated the peace of the assembly. According to Dovring the word skylde meant 'guilty' or 'mutually connected'. ${ }^{216}$ Dovring thus translated the text: "They were obliged to give each other "hostage" and "safe-conduct", all who came here (to the thing) and travel away, all that are not outlawed or banished'. ${ }^{217}$ Dovring considered it likely that there had originally been a formula - which also existed 
in the King's sections of the provincial laws - regarding safe conduct at the things. Thus there was a tradition in the Church section that conserved hostages through the formulistic phrase gilzla oc grutha, which stood outside the other traditions of the provincial laws that described the Eriksgata. ${ }^{218}$

Dovring's interpretation was met by hard criticism. The legal historian Gösta Hasselberg pointed out that mistakes have already been made in early interpretations into Latin during the I 8th century. ${ }^{219}$ A Latin interpretation of the law according to the manuscript from Skokloster was edited by the historian and librarian Magnus von Celse in I735. It was printed as Fragmentum Legis Smolandica in Acta litteraria et scientiarum Suecioe in 1738 , where the Church section was translated as follows:

Pax Dei sanctæque Mariæ sit nobiscum, adventibus och discedentibus; omnibus, qui pace publica fruuntur, qui non extorres neque excommunicati sunt; omnibus denique intra Mioaholt $\&$ Myrtleiks, atque inter Brutarek, \& Biurekis habitantus. ${ }^{20}$

God's peace, and holy Mary's, be with you, who have travelled here and away; for all those who enjoy the peace of the public, who had not been driven out or is banished, all who live within Mjöhult and Mörtlek, all who live within Bråtabäck and Björkö.

(My translation)

Hasselberg refered to an interpretation by Johan Ihre, an I8thcentury historical linguist. In Glossarium Suigothicum, Ihre meant that the word gilsla was a distortion in a transcript. ${ }^{22 \mathrm{I}}$ In his glossary he pointed out alternative forms: Gissel, Gisle, Gisslan, Obses. He translated the phrase from the Church section with:

Illi omnes jure tutelæ frui debent, qui proscripti non sunt aut excommunicati. ${ }^{222}$

Those who are not criminals or outlawed shall have legal protection.

(My translation)

Ihre - like Schlyter - saw gilzla as an error in writing for gizla. ${ }^{223}$ Later interpreters of the text - like Dovring - had, according to Hasselberg, simply used the emendation gizla for gilzla. The A manuscript has gilzla and the B manuscript gildsla. In fact, Hasselberg 
stated, it was a matter of the Old Swedish form gilzli, which is found as name element in the word afgärpabyagilzli, which denote special usufruct and access rights in villages.224 This word is found in two medieval diplomas preserved in original (DS I448, DS I 55 I), dated to I304 and I307. The diplomas concern property rights in Småland. ${ }^{25}$ Hasselberg concluded that the noun gilzli belonged to the adjective gilder in Old Swedish legal writing. The word gilzli was derived from the adjective gill, 'to be valid', meaning to be 'valid' in a legal sense: when a person had legal security and any violation was to be payed for by fines. Finally Hasselberg translated the word skylder with 'just' or 'legitimate' (Sw. berättigad) and gilzli with 'valid' in the Church section. ${ }^{26} \mathrm{He}$ did not reject the interpretation of the words grip or grup as a pledge for peace and safe conduct, but he did not make any comment on Dovring's observation that it was an alliterative word pair.

I have some critical and methodological comments regarding Hasselberg's analysis:

(A) Gils- as a rewriting for gisl-is not rare in Old Norse sources. This is evident from eddic poem Vafpruðnismál, stanzas 3435 with the Old Icelandic forms gils and gisl. ${ }^{27}$ The forms gils-/gisl- are so common in Old Western and East Norse contexts that they are mentioned in several standard texts. ${ }^{228}$

(B) It is not unusual that words were written in different ways in languages without a standardized orthography; most likely the forms $<\mathrm{z}>$ and $<\mathrm{ds}>$ were two ways of writing one sound.

(C) In the Saga literature the words gisl ('hostage') and grið are used as an alliterative word pair, e.g. in Heimskrigla, Saga of St. Olaf: at grið varu sett [-] i gisling. ${ }^{229}$ In the Anglo-Saxon Chronicle (MS E) there is also an alliterative word pair for 'hostage' and 'peace': pa gernde he griðes [and] gisla. ${ }^{230}$

(D) There could be other explanations of usage of the word afgärpabyagilzli: The word occurs only in the two letters, i.e. afgärpabyagilzli could be a local form. ${ }^{231}$

(E) To remove the word element from its context and translate with the Swedish gill is problematic. It is usually the 
Old Swedish gilder that is translated with the Swedish gill. ${ }^{232}$ Hasselberg's claim that the word gilzla in the A manuscript meant gill has a weak support in the sources because that word was gilder (alt. gylder).

Hasselberg's argument is therefore not convincing. In recent editions of the Smålandslagen, Holmbäck and Wessén did not mention or comment on Hasselberg's claims at all. ${ }^{233}$ Given that alliterative phrases occur in Scandinavian medieval laws that reflect older traditions, it might be possible - as Dovring thought - to claim that the Church section of the Smailandslagen was outside the King's section, as it was reproduced in other Swedish traditions.

\section{Violence against hostages en masse}

Sometimes in medieval Scandinavia, conflicting sides used what Kosto refers to as the unilateral hostage form. It was not the question of standing as security for a person, but hostages were used as a means of pressure that aimed at pushing someone for concessions or to undermine a subversive population. The latter form is expressed in the Norwegian law of Magnus the Lawmender (Magnus Lagabøters landslov), and it could also be exemplified by the medieval skaldic poem Runhenda (I I 55) by Einar Skulason (ON Einarr Skúlason) about the Norwegian king Eystein Haraldsson (Eysteinn Haraldsson):

$\begin{array}{ll}\text { Vikverjom galt } & \text { The Mild and generous king } \\ \text { varð pannug hallt, } & \text { Made return against } \\ \text { gọrræði gramr, } & \text { The Vik-dwellers' strife; } \\ \text { gjafmildr ok framr. } & \text { He had luck in battle. } \\ \text { Flest fólk varð hrætt, } & \text { Most folk were afraid } \\ \text { áðr fengi sætt, } & \text { Before they sought peace. } \\ \text { en gisla tók } & \text { He took hostages } \\ \text { sás gjǫldin jók. } & \text { And fines of every man. }\end{array}$

(Transl. Erling Monsen \& A. H. Smith)

The skaldic poem implies that many people were taken as a hostage after a rebellion of warriors in today's Swedish province of 
Bohuslän, and threats were made to use violence against the hostage unless the population stayed calm.

Naturally the purpose of the method of taking many people as hostages was to cause a deterrent effect with an implicit or explicit threat of retaliation against hostages if an agreement was not fulfilled. At the same time, violence against hostages seems to have been unusual and even in cases where it occurred, there may nevertheless have been some restrictions, albeit implicit ones. Massacres are mentioned in chronicles but the same type of violence - that is, mass mutilations - also occurred, which is discussed below.

\section{The story of Thietmar}

In 994, hostages taken from Stade in Lower Saxony were massacred. The German bishop and chronicler Thietmar of Merseburg was personally affected by these events because several of his relatives became victims of the massacre. He later described the events in his chronicle on the history of the city of Merseburg, 908-iо 8.

In June 23, 994 Thietmar's uncles Udo, Heinrich, and Siegfried, met pirates who ravaged their district in a sea battle in the Elbe River. Udo fell in the battle while Heinrich, Siegfried, and Count Adalger had to give up and were taken captive with others. Quickly the news of this misfortune was spread among the Christians. Duke Bernhard, who was staying nearby, immediately sent negotiators who would discuss with the pirates the ransom for the prisoners' release and a peaceful solution.

The pirates demanded an 'enormous sum'. Many contributed to the ransom. Thietmar's mother gave everything she had and could otherwise get hold of. When the pirates had received some of the money, they were given Siegfried, the only son of Heinrich, as hostage, and they also received Gerward and Wolfram in exchange for Adalger, among other people. ${ }^{235}$

The pirates released the prisoners when they received the remaining sum of the money. They only kept Siegfried. As he had no son to stand as security, he asked Thietmar's mother for help. Finally, it was decided that Thietmar himself would depart and enter as hostage. ${ }^{236}$ However, during the night Siegfried managed to escape despite his wounds. A priest was blamed for Siegfried's 
escape. The pirates weighed anchor and lay out in the Elbe River. The next day, Thietmar's cousins and all the other hostages were jettisoned. Before that thay were severly mutilated: noses, ears, and hands were cut off. Then the pirates sailed away. Some of the hostages could be rescued but were marked for life. ${ }^{237}$

It is easy to interpret the massacre through Thietmar's eyes as something unthinkable and horrifying, which may have colored the depiction. In addition, Thietmar, as a clerk, had preconceptions about the inviolability of members of the clergy. But these events were something that happened in his immediate vicinity. Although Thietmar did not witness the massacre himself, his text must be regared as a primary source.

An interesting thing about this description is the complex structures that appear to be found behind the actions of the 'pirates' (most likely Danes or Wends) and the Saxons' perception of what was legal and illegal. For example, the execution of the hostage did not necessarily violate Continental Germanic traditions. As far as I know, there is no Continental Germanic legislation from this period, except the law code Lex Frisionum, that explicitly prohibits the execution of hostages. On the contrary, the law code Lex Salica (ch. 58, $\mathbb{S} 6$ ) states that a hostage could be killed if an agreement was not fullfiled..$^{238}$ This notion seems to have followed all the way into the early modern era, at least when it comes to borgensgeisel. ${ }^{239}$ There are also other reports on the mutilation of hostages in Continental Germanic legislation (see The retaliation of Canute the Great below). This does not mean that people adhered to these traditions in practice.

The actual hostage giving seems to have been correct. In this case, hostage was a third-party guarantee until the ransom was paid. In this form of extortion, the procedure resembles the modern hostage phenomenon. However, one should distinguish between prisoners of war and hostages in this case. The former category was made up of the men who were taken as prisoners in the Elbe River and it is therefore not entirely relevant to classify them as hostages. The true hostages were rather the ones that the 'pirates' required as a guarantee to ensure that the debt was paid. It was when a person tried to escape that the 'pirates' believed that the hostages had been forfeited. In Thietmar's story, the killings 
are described as an unconditional, irrational, action more for the pleasure of perpetrators rather than anything else. But that does not seem to have been the case. Initially, the 'pirates' seem to have followed the rules for the treatment of prominent prisoners of war.

When the mutilation of the hostages was carried out, it might have been an act of revenge. Interestingly, there were noblemen and other important persons among the hostages. The 'pirates' must have considered them as 'expended' and thus dehumanised. But there may also have been a moral that had to do with the killings: these actions could be seen as a preventive.

In the book it has been pointed out how the mutilation of hostages lay explicitly and implicitly within the medieval Scandinavian legislation. Mutilation was actually something that was associated with thralls. Brink believes that the mutilation of slaves grew out of a tradition of the slave system of antiquity. Slaves could be marked by their masters to distinguish them. Their ears could be cut off, they were branded with annealed iron, or the owner's name was tattooed on the slave's body. ${ }^{20}$ Brink equates this practice to livestock branding. The practice survived into Continental Germanic times, and then concerned mutilations of one foot, ears, one hand, tongues, or lips as the mark of thralldom. If a slave escaped, a similar punishment also awaited those who helped the slave to escape, according to Brink. Possibly the marking could also have had a preventive effect because the slave was identified by the deformation. ${ }^{241}$ At the same time, one could also claim that slaves - not the least during antiquity - represented a value and a (future) resource. Marking them through branding or mutilating them may have jeopardized their health, perhaps with a long-term recovery as a result, and this could be costly. Brink is careful to point out that the mutilation of slaves is not supported by sources describing Iron Age Scandinavia. However, in Danish medieval legislation there are references to the cutting of a nostril as the mark of a thrall and in the Norwegian Gulating law there is a note of the truncation of an ear of a thrall woman as a punishment for theft. ${ }^{242}$ Brink argues with these examples that the method of truncation may have occurred during the Viking Age. ${ }^{243}$

There might have been rational reasons behind the mass mutilation at Stade: a marker for what the person was, but also a 
preventive measure. In the year 99I, for example, the Danegeld had been lifted for the first time after the Battle of Mældun in England. As in the case described by Thietmar, it was necessary to ensure that the tribute should be paid and the mutilation was executed as a warning for what was to happen during future expeditions if people disobeyed or acted 'dishonostly'.

Can the size of this conflict have anything to do with the brutality of the actions of the 'pirates'? Was it a small-scale or largescale conflict and, if the latter case, was there a greater inclination for violent behaviour? Some archeologists make a distinction between ritualized warfare and large-scale war. The archeologist Anders Andrén, for example, argues that such distinction may have occurred in Scandinavia with reference to Guy Halsall's investigations on Anglo-Saxon England (450-1050) and Leslie Alcock's on the Celtic parts of Great Britain and Ireland. 244 The ritualized warfare meant that raids were carried out by 'aristocratic' groupings that could give a prestigious booty through goods such as slaves, cattle, and horses. These raids would not change the balance of power. In this type of warfare there was a clear 'criterion' with which the contenders could choose the battlefield. Parts of the war booty could be returned and instead of fighting, a tribute was given that included exchanges of ties of friendship. ${ }^{245}$ The large-scale war, on the other hand, would not have the same 'code of honour' as was found in the ritualized warfare. These wars could instead wipe out communities that were replaced by others:

The conflicts could change the balance of power, by shifting the boundaries of political units and allowing the rule over an area to be wholly or partly taken over by another king. In the whole Anglo-Saxon area, large-scale wars are mentioned roughly every three years, but for each individual kingdom a large-scale conflict occurred roughly every twenty years $[\ldots] . .^{246}$

From the above it is easy to get the impression that all 'small-scale wars' were 'ritualized' and thus less violent. But it can be difficult to draw a clear line between 'small-scale' and 'large-scale'. According to Lavelle, the Great Heathen Army involved complex structures: on the one hand small-scale raids, on the other great hosts in motion involving thousands of people. But it is difficult to 
estimate the number on the basis of chronicles and similar source material. As Lavelle points out:

It is logical to presume that the numbers of belligerents in 'largescale' warfare gradually increased proportionately with the size of political units and as the resources that could be obtained from them increased. By the eleventh century, more resources were certainly needed for warfare: the historical sources bear out the scale of the 1066 campaingns [...]. It does not necessarily follow that peace agreements could have been easier to reach in small scale-warfare; a feud could continue indefinitely until [...] it was settled, while large armies were difficult to keep together for long. [-]. With a large army, peace could very quickly have become a practical necessity. ${ }^{247}$

Small-scale raids could also be bloody and may not be easily distinguished from major warfare. The distinction between ritualized warfare and large-scale warfare is not clear because ritual actions also occurred in the latter case. As far as hostages are concerned, this study has shown the reverse: hostages were used in conflicts between territories. Seeing the ritual actions as something delimited and distinguishable from other societal activities can be difficult in these contexts.

As suggested with the model, it could be more fruitful to observe a development - between war and peace - where it was a question about taking advantage of the resources to get the best possible negotiating position. It does not mean that the term 'ritual warfare' is wrong, but to argue that warfare is 'ritual', the term must be defined more clearly. The hypothesis of 'ritual warfare' can be compared with Lavelle's claim that the symbolism of war and peace was about nothing more than just violence and non-violence between various chieftains/great men in Anglo-Saxon England. ${ }^{248}$ Thus, there was no sharp difference between war on the one hand and 'ritual warfare' on the other in the Anglo-Saxon society. It is not unlikely that a similar pragmatic approach - the symbolism with a message of warning - included the events that took place at Stade in 994, a terror that had devastating consequences for those who were exposed to it. 


\section{The retaliation of Canute the Great}

In Ior4, Canute the Great - according to the Anglo-Saxon Chronicle - 'released' his hostage, while he had their hands, ears, and noses cut off. This event has not been paid much attention to within the research. The action is an example illustrating Kosto's point of view that it was far more common to spare hostage than to kill it. Certainly, there was a kind of 'gentlemanship' between nobles, but the reason could also have been pragmatic: killing the hostage meant that it ended as an idea and institution. Did Canute feel so safe that he could 'spend' his hostage or were there other reasons behind the mutilations?

Between Canute, his father Sven, and Anglo-Saxon England, a number of confrontations occurred until IOI4. These confrontations can be listed after the Anglo-Saxon Chronicle:

994. The siege of London. Olaf Tryggvason and Sweyn Forkbeard recieve Danegeld. ${ }^{249}$

I002. The St. Brice's Day massacre, I3 November. Æthelred II orders the killing of all Danish people in England, because of suspicion of a conspiracy.

I003. The Danes plunder Exeter and enter Wiltshire.

I004. Sweyn arrives to Norwhich with his flett. He burns Norwhich. ${ }^{25}$

I005. The Danish fleet returns to Denmark. There is a great famine in England. ${ }^{251}$

I006. At midsummer the Danes plunder Sandwich. Wessex and Mercia mobilize but cannot defeat the Danes. The Danes go into winterquarter on Isle of Wight.

I007. In the spring of 1007 Æthelred decides to pay Danegeld of 30,000 pounds. ${ }^{252}$

I009. A Danish force comanded by Thorkel the Tall arrives to Sandwich and later to Canterbury. The inhabitants of East Kent make peace with Thorkel and pay him 3,000 pounds. With Isle of Wight as base the Danes ravage Sussex, Hampshire, and Berkshire. 
They go to winter quarters in Kent. After Christmas they plunder and burn Oxford. At the rumor of an army that is about to be sent against them they return to Kent. ${ }^{253}$

Iого. After Easter the Danes arrive in East Anglia and lands at Ipswich. There is a great battle between Danes and Anglo-Saxons during which some of the relatives of Æthelreds fall. Then the Danes control East Anglia and plunder Thetford and Cambridge. The Danes are mounted and can easily move between different parts of England and back to their ships. Consequently there is little time to organise resistance against them. By Christmas they return to their ships. ${ }^{254}$

IOI I. Æthelred sends envoys to the Danes with promises of Danegeld and supplies if they cease with their raids. By then the Danes have ravaged large parts of England. At the same time they have tried to achieve truce (grið) and peace (frið) at the local level, but the plundering continues. Between September 8 and 29, Canterbury is under siege and the Archbishop Ælfeah, together with other men and women belonging to the Ecclesiastical elite, are captured. ${ }^{255}$

IOI 2. After Easter, the Danes receive an amount of 8,000 pounds. Archbishop Ælfeah refuses to have a ransom payed for him. He is executed on April I 9th. Thorkel the Tall comes with 45 ships to Æthelred. He promises to defend the king's land in exchange for supplies and equipment. ${ }^{256}$

IOI3. Sweyn comes up along the River Trent to Gainsborough. The Earl of Northumbria, Uhtred, submits as well as the Danish territories of the Five Boroughs in Mercia. Hostages are given from each shire. Sweyn receives supplies and horses. He travels south and leaves the ship and the hostage to his son Canute. Sweyn goes to Oxford and then Winchester. The residents of these cities give him hostages. However, he cannot go to London where Æthelred and Thorkel are staying. Sweyn goes to Wallingford where the Ealdorman Æthelmær gives him hostage. The whole of England acknowledges Sweyn as king. The residents of London then submit to him and give him hostages. Sweyn requires payment and provision. Thorkel located in Greenwich requires the same. ${ }^{257}$

IOI 4. Sweyn dies on February 3. The Danish Navy chooses Canute as king. Instead the English Council decides to elect Æthelred, 
provided he changes his hard rule. Æthelred sends his son Edvard as a messenger to England and promises to introduce reforms. The English Council and Æthelred, through his delegation, make an agreement that is confirmed by oath. All Danish kings are declared lawless in England forever. Æthelred returns in the spring. Canute makes an agreement with the residents of Lindsey (in Northumbria) to get horses against promise that they will plunder together. Æthelred arrives at Lindsey, which is plundered, but Canute is able to escape by sea. When he reaches Sandwich, he lands the hostage he took after his father. He orders his men to cut off the hands, ears, and noses of the hostages. Canute requests that 2I,000 pounds is to be paid to the army located outside Greenwich. On September 28, parts of England are flooded and many people become homeless. ${ }^{258}$

There may have been several reasons for the mutilation of the hostage: (a) as a warning example, (b) as a desperate measure caused by the stressful situation, or (c) as revenge for deceived agreements. Before we get into these possible reasons, some brief comments on the political situation regarding this case will be made. Obviously, Canute was in a precarious situation. Certainly, his own fleet had given him support and chosen him as king. But the English Council had chosen Æthelred. According to the historian Michael K. Lawson, it was likely that this situation would not have occurred if Sweyn had not died. ${ }^{259}$ After this event, Canute returned to Denmark where his brother Harald II preceded Sweyn. Harald agreed to help Canute with ships and troops in exchange for Harald to rule Denmark.

In IOI 4 both sides in this area of confrontations had access to large armies. This meant high self-esteem. During the previous years when Sweyn took hostages, it had a function that did not differ from other forms of hostages. The number of hostages was possibly larger on this occasion than usual, as hostages were given to show a willingness of substitution or 'generosity' rather than something enforced by violence, even if threats of violence were explicit. If one is to apply the gift theory of Mauss to this example, the hostages handed out to Sweyn may be said to have occurred in a situation in which the gifts reached their culmination, including different demands of Danegeld. According to Mauss, the gift 
meant an obligation to stick to agreements. But what did Canute felt about such commitments?

\section{A ritualistic behaviour?}

The mutilations performed at Sandwich can be compared with the execution of Archbishop Ælfeah in ror 2. According to the AngloSaxon Chronicle, the elder Eadric and some councilors came to London and stayed there until the debt of 8,000 pounds was paid.

On Saturday after Easter (April I9), the Danes became annoyed when the archbishop did not want any ransom to be paid for him. Then they took the archbishop and brought him to gathering place, which in the chronicle is called hustinge (c.f. ON húsping). ${ }^{260}$ They were then drunk on wine. During the Sunday evening after Easter, they killed the archbishop. According to the Chronicle, they threw bones and horns of oxen at him and one of them struck his head with an axe. ${ }^{261}$ The Chronicle expresses that Ælfeah's 'holy blood [then] fell on earth' (his halige blod on ða eorðan feoll) and his 'holy soul was sent to the kingdom of God' (his haligan sawle to Godes rice asende). ${ }^{262}$ The body was brought to London in the morning and Bishops Eadnoð and Ælfhun received it with honors, and Ælfeah was buried in St. Paul's Monastery. There he was later declared a martyr.

Ælfeah was not a hostage but a prisoner of war. Nevertheless, the treatment of him is reminiscent of the massacres at Stade and Sandwich; he had to die when the Danes was in a mood of frustration and under the influence of alcohol. The boundary of what can be considered a ritual act and spontaneous violence may have been floating from the perspective of the Scandinavians.

It is quite possible that it was as a part of ritual-based violence that the archbishop was executed; the violence became legitimate because it was a part of a ceremony that the Chronicle merely suggests. From the Christian point of view, the death of Ælfeah was portrayed by miraculous notes of 'holy blood' flowing out and the 'soul' that came to heaven. Obviously, these are later notifications of the chronicler and they are associated with the Christian intention to make Ælfeah a martyr. Nevertheless the actions of the Danes as reported in the Christian-colored context, which are not 
altogether evident. To conclude: the differences between what can be regarded as 'a ritual act' and what is not is vague. This vagueness can also be observed in the examples with Stade and Sandwich.

In relation to the mutliations of Sandwich, two different legal concepts from the Anglo-Danish area of confrontations can be taken into account: mundbryce, 'breach of the mund' and gripbryce, 'breach of the peace'. The term mundr-meant a personal protection, which, according to Steenstrup, was not used by the Danes. ${ }^{263}$ A violation of the mundr resulted in a fine in accordance with the person's position. According to Steenstrup, this penalty was therefore part of a hierarchical law system that did not exist in the Scandinavian countries which was based on the rights of the individual, and a part of the King's peace. In the Scandinavian legislation one focused on the character of the deed. ${ }^{264}$

In accordance with the Anglo-Saxon mentality, people in a high social position could have had a position with legal protection that the Danish people was not aware of. The Old English term gripbryce encompasses a limited number of crimes, which included crimes against (a) Church peace (cyric grip), (b) protection given by the king's hand (cyniges handgrip alt. handseald grip) and (c) peace in the army. ${ }^{265}$ At the same time, Steenstrup indicated that there was a distinction between how in Scandinavian law the name of grið was regarded as a peace that originated from an individual or a place - while the word grip in England had a more general meaning and originated from the 'king's peace', which covered the whole society. ${ }^{266}$ Canute may not have been unaware of what these breaches meant because they occurred during different peace processes between the Danes and the Anglo-Saxons.

Canute's relationship to the Church of England appears to have been tense at first. Lawson points to the Sermo Lupi, by Archbishop Wulfstan, where Canute is, by way of introduction, presented as Antichrist. ${ }^{267}$ The marriage with Emma may have helped ease the relationship with the Church because she gave great donations to it. Even though Archbishop Ælfeah was executed by men serving under Sweyn, Canute, according to Lawson, could have attempted to approach the Church by transferring Ælfeah's remnants to Canterbury. ${ }^{268}$ 
One can nevertheless conclude that Canute still felt so confident that the consequences of worldly lawsuits did not scare him. Even crimes against the canon law - the hostage included many clerks do not seem to have touched him in this case. Canute thus played a high game with the risk of being excommunicated as Christian. ${ }^{269}$ This could be compared to Kosto, who points out that the excomunication was the only tool that was legitimate for the Church to use against combatants. ${ }^{270}$ The perception of the grid was distinguished between different parties. It is quite conceivable that an authority (a victor) could have had a decisive impact on whether mass violence was practiced. Among other things, this kind of violence did not occur on Canute's way to the throne of England.

At the same time, as Lavelle suggests, questions about authority and responsibility generally appear to have been a gray zone during peace processes in medieval traditions. ${ }^{27 \mathrm{I}}$ Nor can it be argued that the Christian, English side was less restrained, which can be seen in the aforementioned St. Brice’s Day massacre and Æthelred's plundering of Lindsey in Northumbria in IOI4. Naturally this was a reprisal because the residents (or the rulers) made an agreement with Canute. It is likely that Æthelred thought he had the law on his side when the English Council declared each Danish king illegal and the condition for his return to England was that the inhabitants would not act deceitfully against him. ${ }^{272}$ Thus, the law, whether canonical or worldly motivated, became means for rulers to use against their enemies.

\section{Concluding remarks}

In this part examples are given on how rights, laws, and personal interests were not always compatible when hostages was used. The rights of hostages could be analysed from three perspectives:

(I) the individual's rights;

(2) the laws and agreements; and

(3) the moral perceptions of the different societies.

The legal protection could be viewed through peace agreements, something that is reflected in medieval legislation, both 
Continental Germanic and Scandinavian. In these agreements which often included a bilateral hostage form - interests may have existed for the hostage giver to keep a person with a strong social capital who would be a potential hostage for the hostage taker.

One could note that the hostage had a 'legal capacity' in peace agreements. It could manifest itself in witnessing the agreement and that they were able to swear oaths. Those who delivered the hostage appears to have had a key position when it came to taking responsibility for hostages, because, at least in early medieval societies, they were members of councils and assemblies. A ruler's position of power in Viking-age Scandinavian societies was subjected to pressure from subordinate groups with influence over peace, these groupings were probably also able to influence the choice of hostages.

It can be difficult to discern the practical-political situation that underlies the saga and chronicle material regarding the relationship between a ruler and his subordinates, sometimes loosely organised in groupings with intentions of their own. This relationship is not least evident in the peace agreement between Magnus the Good and Harthacnut, as it is describe in Ágrip; the hostages were extradited, while later versions have a softer tone and emphasize the kings' peace efforts. At the same time medieval writers would not mention apparent indulgences towards the opposing side. Although this story is considered to have a low source value, there are different versions of a core story that, fictitious or not, illustrate the difficulties with the saga literature as a source of peace settlements. For medieval writers, it may have been important to report the hostage taking as a triumph of war and peace. The winner's prerogative, to receive hostages, appears in some texts as important. In other cases, hostages ended up in the background, as something unimportant, and in some chronicle traditions they gave way, for example, to stories of victories by divine intervention.

There are other themes in the literature involving persons who acts as hostages: (a) revenge motifs (Vikarr, Walther, Olaf Tryggvason), (b) virtue (William of Malmesbury, Walther) and (c) sacrifice, willingness to volunteer as hostages (William of Malmesbury). In the usual storyline, the hostage situation is depicted as a subordination 
where it was for the protagonists, who were raised by their hostages, to master the situation by being accepted in the new environment, after which some sort of revenge follows. In some stories, the main character is trusted with important tasks. This could be compared to the gift-giving tradition in which proven loyalty was an important component. These cases can, however, not be explained unambiguously. From the perspective of the hostage taker, they may have been due to a close relationship with the hostages. The hostage could later become a future ally, or the purpose was simply controlling a potential enemy. A hostage may have had an interest in building up a social capital for future relations, but this contrasts with the literary examples of revenge motives.

If a male hostage constituted an important social capital, the same could also have applied to some women, even if this may have varied from culture to culture. There are few cases with female hostages in Roman, Continental German, Old English, and Scandinavian sources. Within the research, it has therefore been assumed that they simply did not become hostages but instead (extradited) wives as a part of a peace process. Although the source material makes it an open question whether female hostages existed (it depends on how one evaluates sources such as Waltharius, Ynglinga saga, and Malmesbury's English history), they can be attributed to qualities other than just the being the 'good wife'. This applies in particular to women in the 'heathen' societies, where it is difficult to distinguish between categories such as 'religion' and 'politics'.

The social value of the hostage was intimately associated with its legal rights. The rights were contextually conditioned and can be seen in restrictions on the personal freedom described in various sources. There is no evidence that the hostage would have been regarded as 'holy' and thus not inviolable, the value of the hostages can be considered based on their social capital.

When hostages lost their social capital, the protection could also disappear, but the evidence that they, because of bilateral (or unilateral if it were high-ranking persons) agreements, would have been killed or violated is few. Indications of violence against hostages are found in medieval Scandinavian legislation. In some cases, these are private hostages (the Upplandslagen and the 
Östgötalagen) but in others public hostages (the Upplandslagen). It is quite possible that some of the paragraphs mentioned in this legislation are based on older traditions because there are references to elderly legislations.

From legal texts and sagas it is also apparent that hostages received protection during the peace negotiations and that it could be understood by relating to the Old Norse words for 'peace', friðr and grið. In the former case, it either concerns the peace that prevails in the hall or an everlasting 'peace' in the society: an ideally condition. Although the etymology behind grið is more obscure than friðr, it concerned a temporary protection or an asylum. During the peace meetings, envoys, negotiators, and other participants enjoyed this kind of protection. This is evident from formal expressions in medieval Scandinavian legislation such as ma力 grupum oc gislum in the Äldre västgötalagen and in skylde til gilzla oc grutha in the Smålandslagen.

With the unilateral hostage form, hostages could be taken en masse for providing a means of pressure towards opposing groupings such as in Norway in the Middle Ages with the underlying threat of a massive execution. At the same time, actual punishment of the hostages seems to have been rare. From two cases, Stade in 994, and Sandwich in ror4, some conclusions can be drawn: Pragmatic reasons determined violent acts, morals, and legal protection. There could have been several reasons: Stressful moments during which people felt crowded made them make the decision more or less in desperation. Alternatively, one party felt that the agreement was breached. Another possible reason was that it could serve as a warning (in an area, a city, etc.). It is not possible to speak of 'morality' in a modern sense. One might be able to talk about some respect for legal rules, but it seems rather to be related to how the law was used and interpreted, naturally from a biased, subjective perspective.

In the meeting between non-Christians and Christians, there may have been different views on such legal rules, which can be explained by the fact that these are different traditions. That some warlords were Christians hardly constituted a guarantee of the security of the hostage. Law, politics, and religion assumed each 
other in these contexts in a pragmatic way. This can be compared to the hostage phenomenon of the modern times, when it became more associated with retaliation. At the same time, Roscoe Pound claimed that retaliation was an institution 'as old as hostage'. Nevertheless, what was perceived as betrayal and thus the right to reprisals differed. The perception of who was an important person may also have differed. To avoid violence in these contexts, communication and transparency became important for the various parties both during and after the negotiations.

\section{Notes to Part IV}

I. von See I964 I03 ff.; Sundqvist 2005: 275.

2. In Sundqvist 2005: 275 .

3. Althoff 2004; Kosto 201 2: 32 f., 34 .

4. Kosto 2OI 2: 3 I.

5. Grágás: lagasafn íslenska pjódveldisins ([ed.] Gunnar Karlsson et al.): 95 f. (Ch. 23).

6. Kosto 20I 2: 2I, 84 .

7. Annales Alamannici ([ed.] Pertz): 56 (year 9I3); Kosto 201 2: 84.

8. Tacitus, Historiarum libri ([ed.] Fisher): 77 (book 4: 79. I).

9. Whitney Mathisen I993: 34; Passio acaunensium martyrum.

Iо. Beowulf ([ed.] Klaeber): 472; Brink 2003: I05.

I I. Quellen zur Karolingischen Reichsgeschichte, Annales Vedastini ([ed.] Rau): 302 f. (year 882).

I2. Kershaw 20II: I8.

I3. Kosto 20I2: $83 \mathrm{f}$.

I4. Kershaw 20II: I8.

I 5. In Bergman I990: 199.

I6. Jordanes, Getica ([ed.] Nordin): I94 f. (Ch. 299); C.f. Kershaw 2OII: 2I; Olsson 2OI 2: 75. 
I7. [Plutarchos] Bíoi Parállēloi ([ed.] Theander), 209 f. (Ch 29).

I 8. Plutarchos] Bíoi Parállēloi ([ed.] Theander), 209 f. (Ch 29).

I9. Weiner I988; Olsson 2012: 66.

20. Lavelle 2006: 272.

2I. von Olberg I998: 200. I have not been able to confirm this hypothesis in the Edictus Rothari.

22. Mathisen I993: 34 .

23. Kosto 2OI 2: 38 .

24. Watsoni 993: 34; Elbern I990: $97 \mathrm{ff}$.

25. Watsoni993: 34 .

26. See Pelteret 2005: 5 ff.

27. Olsson 20I2: 68 .

28. Cf. Lavelle 2006: $275 \mathrm{f}$.

29. Annales Bertiniani ([ed.] Buchner): 48 ff. (year 839).

30. Annales Bertiniani ([ed.] Buchner): 48 ff. (year 839).

3I. En pá var Sveinn frá fallinn í Danmǫrku ok svá Knútr faðir hans í Englandi, ok réð pá fyrir Danmǫrku bróðir Sveins, Hǫrða-Knútr at nafni, ok helt her á móti Magnúsi ok fundusk í Brenneyjum. Fóru vitrir menn á meðal ok mæltu til sættar ok gerðu með peima hætti, at með pví at Knúti bótti sem hann ætti rétt tilmæli til Nóregs, pá hafði faðir hans aflat ok bróðir hans at setit-Mognúsi pótti ok illt misheldi pat er faðir hans hafði haft af Knúti, svik ok lands flótta ok lífs aftakpá sløru peir bó máli í pá sætt at sá peira er lengr lifði skyldi taka við bọ́ðum landum ok hvárr sínu ríki ráða meðan báðir lifði peir, ok settu gísla, ok andaðisk Knútr fyrri, en Mǫgnús tók pá víð Danmǫrk fyr útan gagnmæli, pvíat synir bǫztu manna vọ́ru í gíslinginni. Ágrip af Nóregskonungasogum ([ed.] Driscoll): 48 (text) (Ch. XXXVI). 32. Ágrip af Nóregskonungasogum ([ed.] Driscoll): 49 (transl.) (Ch. XXXVI).

33. Krag I995: I69; Bagge 20I4: 32. 
34. Krag I995: I69.

35. Fritzner (I883-1896) I973: 489; Lexicon poeticum ([ed.] Finnur Jónsson): I 54; Palm 2004: 492.

36. Fagrskinna ([ed.] Bjarni Einarsson): 2 I0 (Ch. 47).

37. Heimskringla III. Magnúss saga ins góða ([ed.] Bjarni Aðalbjarnarson): I2 f. (Ch. 5).

38. Magnus was born about I024 and Harthacnut about IOI8 (P. Sawyer 200I: 65).

39. Ok er pessi ófriðr hafði staðit um hríð milli konunganna pá gørði hvárrtveggi mikinn skaða á annars ríki. Pat leiðisk bœndum ok vildu gøra í millum sín betra vanða. Samnask pá saman bœendr ór hvártveggju ríkinu ok gøra ráo með vizku ok mikilli hamingju fyrir họnd fyrir konunganna, er báðir váru œskumenn en auðráð sínum mǫnnum ok hœgir, ok gørðu nú fund í milli sín í Elfi Morkinskinna ([ed.] Pórður Ingi Guðjónsson \& Ármann Jakobsson): 27 (Ch. 3).

40. Morkinskinna ([ed.] Andersson \& Gade): IoI (Ch. 2).

4I. Knytlinge saga ([ed.] Ægidius): 36.

42. Ármann Jakobsson 2005: 397.

43. Norges kongekrønike ([ed.] Gunnarssøn): I63 f.

44. Danmarks middelalderlige annaler ([ed.] Kroman): I 92 f. (stanza I93 f.).

45. Saxo Grammaticus, Gesta Danorum = The History of the Danes I ([ed.] Friis-Jensen): 775 (Book ro).

46. Allen 2006: I ff.

47. Allen 2006: 4 .

48. Lavelle 2006: 295.

49. Lavelle 2006: 296.

50. Commentarii de Bello Gallico ([ed.] Kraner): 444 f. (Ch. 89, book VII). Dio Cassius ([ed.] Cary): 49 (Ch. 4I, book XL). 
5I. Jón Skaptason I983: I 57.

52. Jón Skaptason I983: I 57.

53. Annales Bertiniani ([ed.] Buchner): 50 f. (year 839).

54. Baker 2013: 95 .

55. Lynch I998: I3 I f., 2 I 5 f.

56. See Rydving I993: Io ff.

57. Kosto 201 2: 60.

58. Kosto 20I 2: 60.

59. Boken om Ansgar ([ed.] Hallencreutz): 58 (Ch. 30).

60. The number 30 may also be a topos. The missionary Willibrord in the eighth century returned from a visit to the Danish king with 30 boys according to Alcuin (The Life of Willibrord, c.796, Ch. 9).

6I. Sundqvist (2002: 2I $5 \mathrm{ff}$.) points out that lottery throwing in favour of Christians is probably a literary topos because it is a recurring theme in other bishop chronicles. It can also be compared to cases where, for example, the devil is said to speak through idols and then is revealed unmasked by missionaries or Christians (see Hultgård I997: I4 f.).

62. Both silver money and the number 30 are found in the Gospel of Matthew (Matthew 26: 48). Also, Nebuchadnezzar marched againgst Jerusalem in the ninth year of Zedekiah and the ninth day of the fourth month the enemy broke into Jerusalem (2 Kings 25: I-4).

63. Nerman I942: I 20.

64. Waltharius ([ed.] Ørbæk): I3 f. (stanzas 6I-95). Götreks saga ([ed.] Malm): 22-27 (Ch. IV).

65. Ágrip af Nóregskonungasogum ([ed.] Driscoll): 28 (text), 29 (transl.) (Ch. I 8). It is the same history in Heimskringla I, Ólafs saga Tryggvasonar ([ed.] Bjarni Aðalbjarnarson): 230 f. (Ch. 6-7).

66. Jordanes, Getica ([ed.] Nordin): I76 f. (text), I79 f. (transl.) (Ch. 270-272). 
67. Jordanes, Getica ([ed.] Nordin): I 84 (text), I 85 f. (transl.) (Ch. 282).

68. Tacitus, Germaniens historie, geografi og befolkning [Germania] ([ed.] Bruun \& Lund): 55 f. (Ch. 20); Olsson 20I2: 66.

69. Mauss 2002: I $6 \mathrm{f}$.

70. See Allen 2006: I 27 ff., I3 I ff., I 38 ff.

7I. Priscus fr. 3; Bury I958: 24I.

72. Annales regni Francorum ([ed.] Pertz): I37 (year 8I2).

73. The Song of Roland, the Oxford Version ([ed.] Owen): IOI (stanza 3033 ).

74. Nordisk familjebok (Uggleupplagan): 975 f. Lat.

75. Lavelle 2006: 272, n. 9.

76. Anglo-Saxon Chronicle MS F ([ed.] Baker): ıo5 f. (year ıог 3 ).

77. Anglo-Saxon Chronicle MS F ([ed.] Baker): Io6-III (years IOI4-IOI7, IO2I).

78. Heimskringla, Ólafs saga helga ([ed.] Bjarni Aðalbjarnarson): I6I-I74 (Ch. 97-I03). See Beuermann 20I I: I Io.

79. Heimskringla II, Ólafs saga helga ([ed.] Bjarni Aðalbjarnarson): I6I-I68 (Ch. 98-ı00); Orkneyinga saga ([ed.] Finnbogi Guðmundsson): 28-36 (Ch. I3-I7).

80. Heimskringla II, Ólafs saga helga ([ed.] Bjarni Aðalbjarnarson): I68 ff. (Ch. Iо0, I02); Orkneyinga saga ([ed.] Finnbogi Guðmundsson): 36 (Ch. I7).

8I. Heimskringla II, Ólafs saga helga ([ed.] Bjarni Aðalbjarnarson): I 68 ff. (Ch. Iоo); Orkneyinga saga ([ed.] Finnbogi Guðmundsson): 35 f. (Ch. I7).

82. Heimskringla II, Ólafs saga helga ([ed.] Bjarni Aðalbjarnarson): I72 (Ch. I02); Orkneyinga saga ([ed.] Finnbogi Guðmundsson): 40 f. (Ch. I9).

83. Orkneyinga saga ([ed.] Finnbogi Guðmundsson): 4I (Ch. I9). 84. Orkneyinga Saga ([ed.] Hermann Pálsson \& P. Edwards): 49 (Ch. I9). 
85. Heimskringla II ([ed.] Bjarni Aðalbjarnarson): I70 (Ch. Іог); Orkneyinga saga ([ed.] Finnbogi Guðmundsson): 39 (Ch. I8).

86. Orkneyinga saga ([ed.] Finnbogi Guðmundsson): 38 (Ch. I8).

87. Heimskringla II ([ed.] Bjarni Aðalbjarnarson): I72 (Ch. Iо2); Orkneyinga saga ([ed.] Finnbogi Guðmundsson): 4I (Ch. I9).

88. In Heimskringla II ([ed.] Bjarni Aðalbjarnarson): I72 (Ch. IO2); Orkneyinga saga ([ed.] Finnbogi Guðmundsson): 4I (Ch. I9).

89. Miller I990: I23.

90. Miller I990: I $23 \mathrm{ff}$.

9I. Miller I990: I24.

92. Miller I990: I24.

93. Miller I990: 172.

94. Laxdœela saga ([ed.] Einar Ól. Sveinsson): I28-I32 (Ch. 43); see Olsson 20I2: 7I ff.

95. Sturlunga Saga I, Íslendingasaga ([ed.] Gudbrand Vigfusson [Guðbrandur Vigfússon]): 244 (Ch. 43).

96. Miller I990: I24.

97. Auður Magnúsdóttir 2003: 73.

98. See Auður Magnúsdóttir 2003: 68 f.

99. Jón Viðar Sigurðsson I999: 2 IO f., 2 I4, 2 I9 f.; 20 I I: IOI f.

I00. Lavelle 2006: 284 .

ıог. Anglo-Saxon Chronicle F ([ed.] Baker): 5 I (year 757); Kosto 2OI 2: 64 .

I02. Waltharius ([ed.] Ørbæk): I 3 f. (stanzas 6I-95).

I03. Gautreks saga (Ch. 3-4).

The story of Vikar and Herpjofr is largely confirmed by the skaldic poem Vikarsbalkr which some believe may originate from the Iooos (see Naumann 2005: 538).

I04. Lavelle 2006: 270. 
I05. Lavelle 2006: 270.

I06. Enright I996: 20 ff., 283 ff. For critical point of views on Enright's hypothesis, see Baker 2013: I 83 ff.

I07. See Sundqvist 2007: 74, n. 44.

I08. Beowulf ([ed.] Klaeber et al.): Ch. XVI, 39 (I I I 4-I I I7).

I09. Waltharius ([ed.] Ørbæk): I4 (stanzas I I3-I I 5), I 8 (stanza 260).

I IO. Kershaw 20II: 2 I.

III. Sanmark 20I4: $94 \mathrm{f}$.

I I2. Sanmark 20I4: 95 f.; Mundal I994: 595.

II3. Sanmark 20I4: 96.

I I 4. Laxdoela saga ([ed.] Einar Ól. Sveinsson: 28, 50 f. [Ch. I3, 20]). I I 5. Landnámbók, Sturlubók ([ed.] Finnur Jónsson: I6I [Ch. I I2]). II6. Sanmark 20I4: 99.

I I7. Roskrecht (Rosbach: 58 [Ch. I. 50]).

I I 8. Germaniens historie, geografi og befolkning [Germania] ([ed.] Bruun \& Lund: 44 f. [Ch. 9]).

I 19. Statius Silvae (net edition, The Latin Library): I, 4 (line 90).

I 20. Näsström I 995: 46 f.; Sundqvist 2007: 70 f.

I2I. Raudvere 2003: I 25 ff.; Sundqvist 2007: 68 f.

I22. Raudvere 2003: I25 ff.; Sundqvist 2007: 68 f. A possible counterpart to the presence of 'magicians' has been put forward by Dillmann (2006).

I23. Ney 20I 2: 80, 82, n. I 8 f.

I 24. Cf. Kaliff \& Sundqvist 2004: $63 \mathrm{f}$.

I 25. Aðalheiður Guðmundsdóttir 20I 2: 67 ff.

I26. Knytlinge saga ([ed.] Ægidius) 3 I. See also Knútsdrapa, by Sigvat skald in Den norsk-islandske skjaldedigtning A I ([ed.] Finnur Jónsson): $248 \mathrm{ff}$.

I 27. Encomium Emmoe Reginae, Book II, ch. 3 I. 
I28. Encomium Emmoe Reginae, Book II, ch. 3 I.

I29. Ármann Jakobsson 2005: 398.

I30. Encomium Emmoe Reginae, Book II, ch. 35 .

I3I. Williams 2003: 53.

I32. William of Malmesbury, Gesta regum Anglorum (ed. Mynors et al.): 300 (text), 30I (transl.) (Ch. I77, I).

I33. William of Malmesbury, Gesta regum Anglorum (ed. Mynors et al.): 300 (text), 30 I (transl.) (Ch. I77, I). See Fenton 2008: 55.

I34. Ney 2006: 7I ff.; Näsström 2009: I72 f.

I35. Saxo Grammaticus, Gesta Danorum = The History of the Danes I ([ed.] Friis-Jensen): 633 ff. (Book 9, 4.I-4.2).

I36. Näsström 2009: I72 f.

I37. ODCW, 3 I.

I3 8 . Hedenstierna-Jonson et al. 20 I 8: $853 \mathrm{ff}$.

I39. Stylegar blogg http://arkeologi.blogspot.com/20I7/Io/kvinnekriger-viking.html.

I40. Gardela 2013: 306.

I4I. Gardela 20I3: 306.

I42. Den frankiske Rigsannaler, Vikingerne $i$ Franken ([ed.] Albrechtsen): I3 ff. (years 804-8 Iо).

I43. De Carolo Magno (Gesta Caroli Magni), Book II, Chapter I 3 .

I44. Elbern I990: I Iо.

I45. Walker 2005: kap I; Rhōmaikē arkhaiologia, V: 34: I-2.

I46. Allen 2003: 94.

I47. Walker 2005: Ch. I.

I48. Beck I998: 464. During the Gallic wars, the Suebian ruler Ariovistus fought against Caesar. Caesar wanted to negotiate with Ariovistus and chosed Gaius Valerius Procillus as messenger - a Helvetian who had gained Roman citizenship - and whom Caesar believed the Germans would not misunderstand. He also chose M. 
Mettius who had the rights of 'guest friendship' with Ariovistus (qui hospitio Ariovisti utebatur) since before. But Ariovistus had them locked up in the belief that they were spies. After the final battle, Caesar found Ariovistus in fetters. Three times had the Suebians cast lots (sortibus consultum) to see whether the life of Ariovistus would be spared or not (C. Iuli Caesaris commentariorum de bello gallico liber primus [net edition, the Latin Library, Ch. 47]).

I49. Widukind, Sächsiche Geschichten ([ed.] Hirsch): Io f. (Book I, Ch. 6); Althoff 2004: I 40.

I 50. Gylfaginning, Edda (a) ([ed.] Faulkes): 26 ff. (Ch. 33-34).

I 5 I. Mathiesen I993: 35 .

I 5 2. Jordanes, Getica ([ed.] Nordin): I 29 (text), I 30 (transl.) (Ch. I 84).

I 53. Lex Frisionum: ch. XX. $\mathbb{\text { I }}$ (text), (transl.).

I 54. Kosto 20I 2: $36 \mathrm{ff}$.

I 5 5. Kosto 20I 2: 38 .

I 56. Gundersen I960: 332 .

I 57. Magnus lagabøters landslov III ([ed.] Taranger): 3 I (Ch. 3, $\mathbb{S} 4$ ). I 5 8. Orkneyinga páttr, Flateyjarbók II ([ed.] Gudbrandr Vigfusson): 5 I 8. I 59. E.g. Orkneyinga saga ([ed.] Finnbogi Guðmundsson): I70 (Ch. 75). I60. According to the Acts of the Apostles 9: 3-5 Saul (Paulus) is blinded by God. Three days later his sight is restored by Ananias of Damascus (Acts of the Apostles 9: I7).

I6r. Heimskringla II, Ólafs saga helga ([ed.] Bjarni Aðalbjarnarson): I05 (Ch. 75).

I62. Meyer I960: 33 I.

I63. Östgötalagen, Svenska landskapslagar I ([ed.] Holmbäck): 67, n. 8 .

I64. Östgötalagen, Svenska landskapslagar I ([ed.] Holmbäck): 54 (Dråpsbalken II, \2); (Vådamålsbalken XXXIV, \I); (Rättegångsbalken III, \2). 
I65. Amira I882a: 69I; Lutteroth I922: 25.

I66. Manhelgdsbalken, Upplandslagen ([ed.] Schlyter): I44 (flock I $2, \mathbb{8} 8$.

I67. Manhelgdsbalken, Upplandslagen ([ed.] Holmbäck): 95 (flock I $2, \mathbb{8} 8$.

I68. Upplandslagen, Svenska landskapslagar I ([ed.] Holmbäck): I 24, n. 83 .

I69. Upplandslagen, Svenska landskapslagar I ([ed.] Holmbäck): 94 pp. (Manhelgdsbalken $\mathbb{I} \mathrm{I}-\mathrm{IO}$ ); Upplandslagen, according to Cod. Holm. B I99 and the edition of I607 ([ed.] Henning): I 27 ff. (I 2, $\mathbb{S}$ I-I 2).

I70. Upplandslagen, Svenska landskapslagar I ([ed.] Holmbäck): I 24, n. 8 I.

I7I. Upplandslagen, Svenska landskapslagar I ([ed.] Holmbäck): I 23, n. 72 .

I72. Danmarks riges breve ['The Letters of the Realm of Denmark'] I I 2 I I-I 223 ([ed.] Skyum-Nielsen): I 90 (diploma nr 2 I7).

I73. Danmarks riges breve ['The Letters of the Realm of Denmark'] I I 2 I I-I 223 ([ed.] Skyum-Nielsen): I92 (diploma nr 2I 7, \$ IO).

I74. indtil hr. ærkebiskoppen av Köln og oftnævnte greve av Schwerin [Henrik] bringer i erfaring, om de kan bevæge Danmarks konger til att erhverve sig hr. kejserens og hr. kongens nåde enten ved betaling eller ved at tilbagegive de lande, som de har berøvet kejser og rige, eller hved hvilke som helst andre midler.

Danmarks riges breve ['The Letters of the Realm of Denmark'] I I 2 I I-I 223 ([ed.] Skyum-Nielsen): I 92 (diploma nr 2I7, \ II).

I75. Ulsig 20I I: 8 I f.

I76. Hall \& Meritt 2002: I38; Beowulf ([ed.] Klaeber et al.): 380 .

I77. Hall \& Meritt 2002: I3 $8 \mathrm{f}$.

I78. Steenstrup (I 882) I972: 248 .

I79. Kershaw 20I I: 30. 
I 80. Erfidrápa Óláfs helga, Den norsk-islandske skjaldedigtning A I ([ed.] Finnur Jónson): 259 (I2, stanza Io). Kuhn I968: I03.

I 8I. Vellekla, Den norsk-islandske skjaldedigtning A I ([ed.] Finnur Jónson): 126.

I82. Edda ([ed.] Neckel \& Kuhn): I9 (stanza I6). Hástein Hrómundarson halta (Hásteinn Hrómundarson halta), Lausavísur, Den norsk-islandske skjaldedigtning A I ([ed.] Finnur Jónson): 97 (stanza 4 ).

I 83. Edda ([ed.] Neckel \& Kuhn): 82 (Ch. 29).

I 84. Lexicon Poeticum ([ed.] Finnur Jónsson): I 54.

I 8 5. Tiefenbach I995: 595 .

I 86. Elmevik 20I 3: 42.

I 87. In Fritzner (1883-96) I973: 487.

I88. See Fritzner (1883-96) I973: I72.

I 89. See Peterson 2007: I04.

I90. Eyrbyggia saga ([ed.] Einar Ól. Sveinsson): 9 (Ch. 4).

I9I. Eyrbyggia saga ([ed.] Einar Ól. Sveinsson): Io (Ch. 4).

192. The Annals of Fulda ([ed.] Reuter): 92 (year 882).

193. The Annals of Fulda ([ed.] Reuter): 93 (year 882).

I94. Bøe I960: 463; Lexicon Poeticum ([ed.] Finnur Jónson): 203.

195. Erfidrápa um Harald konung harðráða, Den norsk-islandske skjaldedigtning A I ([ed.] Finnur Jónson): 352 (stanza I 5).

I96. Af Ragnars saga loðbrókar, Den norsk-islandske skjaldedigtning A 2 ([ed.] Finnur Jónson): 232 (II, stanza 3).

I97. Atlamál in grœnlenzko, Edda ([ed.] Neckel \& Kuhn): 252 (Ch. 33); Den norsk-islandske skjaldedigtning A I ([ed.] Finnur Jónson): 5 I 7 (stanza I4 b).

198. The Concise Oxford Dictionary of English Place Names ([ed.] Ekwall): 205. In Old English there was likewise a special name for a law that meant a temporary, local peace, griðlagu (Borden I982: 697). 
I99. Edda ([ed.] Neckel \& Kuhn): 96. C.f. the historian of religions Tommy Kuusela (20I7: I09 f.) who maintains that the use of grið was a part of certain rules of conduct in the halls. Kuusela (2017: I63 ff.) gives examples from various myths on how Odin and Thor (ON Pórr) breaks the truces when dealing with the jötnar in halls, the gods which are then mentioned as griðniðningr, 'truce-breaker'.

200. Steenstrup (I882) I972: 248 .

201. Eyrbyggja saga ([ed.] Einar Ól. Sveinson): I23 (Ch. 44).

202. Hakonarmál, Den norsk-islandske skjaldedigtning A I ([ed.] Finnur Jónson): 67 (stanza I6).

203. Eyrbyggia saga ([ed.] Einar Ól. Sveinson): I 23 (Ch. 44)

204. This formula is comparable to the Old English word frì gissl (I982: 483).

205. Grágás, Vígslóði ([ed.] Gunnar Karlsson et al.): 282 (\$ I22).

206. Heimskringla II, Óláfs saga helga ([ed.] Bjarni Aðalbjarnarson): I 5 (Ch. 80).

207. Upplandslagen, kungabalken II, ([ed.] Henning): 59.

208. Grágás: lagasafn íslenska pjódveldisins ([ed.] Gunnar Karlsson et al.): 282 (Ch. I22).

209. In Dovring I947: 258.

2 Io. Smålandslagen, Svenska landskapslagar 5 ([ed.] Holmbäck): 423 (I).

2 I I. Samling af Sveriges gamla lagar ([ed.] Schlyter): XXI f.

2 I 2. Smålandslagen, Svenska landskapslagar 5 ([ed.] Holmbäck): 435 .

213. See Harrison 2009: 279.

2I4. Smålandslagen, Svenska landskapslagar 5 ([ed.] Holmbäck): 435 .

21 5. Dovring I947: 259.

216. Dovring 1947: 260.

217. Dovring I947: 260.

218. Dovring I947: 260. 
219. Hasselberg I948: 44 .

220. In Hasselberg I948: 45.

22I. Hasselberg I948: 44.

222. Hasselberg I948: 45 .

223. Hasselberg I948: 45 .

224. Hasselberg I948: 48 .

225. Database of the National Archives of Sweden, Nationell Arkivdatabas (https://sok.riksarkivet.se) (2015-10-22).

226. Hasselberg I948: 50.

227. Edda ([ed.] Neckel \& Kuhn): I03 (stanza 34-35).

228. Alexander Jóhannesson I 956:306; de Vries I96 I: I67; Petersson 2007: 79; see Olsson 20I2: 6I.

229. Cf. the skaldic poem Runhenda: gisla and gigldin.

230. Anglo-Saxon Chronicle MS E (ed. Irvine): 82 (year I048); cf. Steenstrup (I 882) I972: 249, n. 5 .

23I. Riksarivets databas 20I 5-O3-I2; cf. Söderwall I884-I9I8: 9.

232. See Söderwall I884-I9I8: 399 f.; Hellquist I922: 28I; Ernby 2008: 2 II.

233. Cf. Lars-Olof Larsson I975: I6.

234. Haraldssönernas saga, Nordiska kungasagor III ([ed]. Johansson): 263 (text), (Ch. I9); Heimskringla, History of the Norse Kings: Sigurd, Inge, and Eystein, the sons of Harald Gilli ([ed.] Monsen): 678 (transl.), (Ch. I9).

235. Thietmar, Chronik ([ed.] Trillmich): I 38 ff. (text), I 39 ff. (transl.) (Book 4 Ch. 23).

236. Thietmar, Chronik ([ed.] Trillmich): I4O (text), I4I (transl.) (Book 4 Ch. 24).

237. Thietmar, Chronik ([ed.] Trillmich): I40 ff. (text), I4 I ff. (transl.) (Book 4 Ch. 25).

238. Pound I959: I86. 
239. Pound I959: I86. According to the legal historian Roscoe Pound, with reference to Lutteroth, a borgensgeisl could either be killed or mutilated (Pound I959: I 86).

240. Brink 20I2: I9I.

24I. Brink 20I2: I9I ff.

242. See 20I2: I93.

243. Brink 20I2: I93.

244. Andrén 20 I 4: 98; Halsall I989; Alcock 2003: I I9 ff.

245. Andrén 20I4: 99.

246. Andrén 20I4: 99.

247. Lavelle 2000: 42.

248. Lavelle 2000: 40.

249. Anglo-Saxon Chronicle MS E ([ed.] Irvine): 6I ff. (year 994).

250. Anglo-Saxon Chronicle MS E ([ed.] Irvine): 64 ff. (years I002-I004).

25I. Anglo-Saxon Chronicle MS E ([ed.] Irvine): 65 (year I005).

252. Anglo-Saxon Chronicle MS E ([ed.] Irvine): 66 (year I007).

253. Anglo-Saxon Chronicle MS E ([ed.] Irvine): 66 ff. (year Ioo9).

254. Anglo-Saxon Chronicle MS E ([ed.] Irvine): $67 \mathrm{ff}$. (year ıого).

255. Anglo-Saxon Chronicle MS E ([ed.] Irvine): 68 ff. (year Ior I).

256. Anglo-Saxon Chronicle MS E ([ed.] Irvine): 69 (year Ior 2).

257. Anglo-Saxon Chronicle MS E ([ed.] Irvine): 69 ff. (year гог 3$).$

258. Anglo-Saxon Chronicle MS E ([ed.] Irvine): 7I (year Ior4).

259. Lawson 2004: 27.

260. The hustinge was a congregation in 'the prince's' or the warlords own home where he held meetings with the hird (Lexicon Poeticum [(ed.) Finnur Jónson]: 296; Fritzner [ı883-96] I973: I08). In some royal decrees, ancient sagas and medieval laws it is mentioned how the king could convene for the hustinge (Fritzner [1883-96] I973: 
I08 f.). The king could give custody (grið) to a criminal at this place (Fritzner [1883-96] I973: I08). Obviously, the hustinge was multifunctional, where religious, political, and legal elements existed, which can be compared to Stefan Brink's hypothesis about the multifunctionality of the thing (cf. Fritzner [1883-96] 1973: 108).

26I. The custom of throwing bones at a person could have a parallel in Hrólfs saga kraka og Bjarkarimur ([ed.] Finnur Jónsson): 64 ff.

262. Anglo-Saxon Chronicle MS E ([ed.] Irvine): 69 (year Ior 2).

263. Steenstrup (I882) I972: 360.

264. Steenstrup (I882) I972: 360.

265. Handgrið was a part of griðbryce (Steenstrup [1 882] I972: 363) and is mentioned in the peace treaty (Nov. 92 I [- 938?]) between Alfred and Guthrum, Gesetze der Angelsachsen I ([ed.] Lieberman): I 28 [text]).

266. Steenstrup (I882) I972: 250, 362.

267. Lawson 2004: II9.

268. Lawson 2004: I3 I f.

269. Lawson 2004: I20, I3 I ff.

270. Kosto 2012: I33.

27I. Lavelle 2000: 4I.

272. Anglo-Saxon Chronicle MS E (ed. Irvine): 7I (year IoI4); Anglo-Saxon Chronicle MS F (ed. Baker): Io6 f. (year Io I4). 